\title{
A one-pot, water compatible synthesis of pyrimidine nucleobases under plausible prebiotic conditions
}

Hidenori Okamura, ${ }^{a}$ Sidney Becker, ${ }^{a}$ Niklas Tiede,${ }^{a}$ Stefan Wiedemann, ${ }^{a}$ Jonas Feldmann ${ }^{\mathrm{a}}$ and Thomas Carell $^{a^{*}}$

\author{
${ }^{\text {a }}$ Center for Integrated Protein Science (CiPS ${ }^{\mathrm{M}}$ ) at the Department of Chemistry, Ludwig-Maximilians- \\ Universität München, Butenandtstr. 5-13, 81377 München, Germany, \\ *E-mail: thomas.carell@Imu.de
}

Published in Chem. Commun. 2019, 55, 1939-1942 on 07.01.2019, DOI: 10.1039/C8CC09435G

\begin{abstract}
Herein, we report a new prebiotically plausible pathway towards a pyrimidine nucleobase in continuous manner. The route involves simultaneous methylation and carbamoylation of cyanoacetylene-derived $\alpha, \beta$-unsaturated thioamide with $N$-methyl- $N$-nitrosourea (MNU) in aqueous media. This provides $S$-methylpyrimidinone in one-pot, which can be converted into a variety of 4substituted pyrimidine nucleobases including cytosine and uracil.
\end{abstract}

\section{Main Text}

Elucidating the chemical process that gave birth to biologically essential molecules on the early Earth is key for understanding the origin of life. Among the major biomolecules, RNA is thought to have played a central role during chemical evolution. RNA can store genetic information and at the same time has the potential to catalyse chemical reactions. ${ }^{1-3}$ Therefore, RNA might be able to establish self-replicating systems amenable to Darwinian evolution. ${ }^{4,5}$ The essential components of RNA are purine $(A, G)$ and pyrimidine $(U, C)$ nucleobases, which form WatsonCrick $\mathrm{H}$-bonds. $\mathrm{H}$-bonding and $\pi$-stacking allows RNA to fold into complex shapes and modified nucleobases that are also part of contemporary RNA provide functionality far beyond what is observed with DNA. ${ }^{6}$ This structural diversity raise the question of how the constituting RNA nucleobases could have emerged. Did the chemical reactions that occurred on the early Earth provide only the canonical nucleosides, or were a plethora of different structures created, followed by a chemical evolution process that led to the selection of the fittest molecules for information encoding? An important additional feature of the pyrimidine and purine heterocycles is that they may be capable of providing a chiral field via dehydrated crystals ${ }^{7,8}$ that could have played a role in the emergence of chirality. Finally, they can stabilize aggregates of amphiphiles and as such they could have been involved in forming cell-like vesicle surrounded by amphiphilic membranes. ${ }^{9}$ All these properties make research about the chemical origin of the pyrimidine and purine heterocycles a pressing problem.

In pioneering work, Ferris et al. demonstrated cytosine formation from urea or sodium cyanate and cyanoacetylene. ${ }^{10}$ Miller et al. reported cytosine synthesis by heating a saturated solution 
of urea with cyanoacetaldehyde. ${ }^{11}$ The high reactivity of these cyano-derivatives, however, brings into question their accumulation to significant concentrations. ${ }^{12,13}$ Alternatively, pyrimidine nucleobases can also be generated from formamide under high energy conditions (e.g. heat, spark discharges) in the presence of meteorite or mineral powder. ${ }^{14,15}$ These conditions, however, may be too harsh for complex chemical systems that may have given rise to RNA.

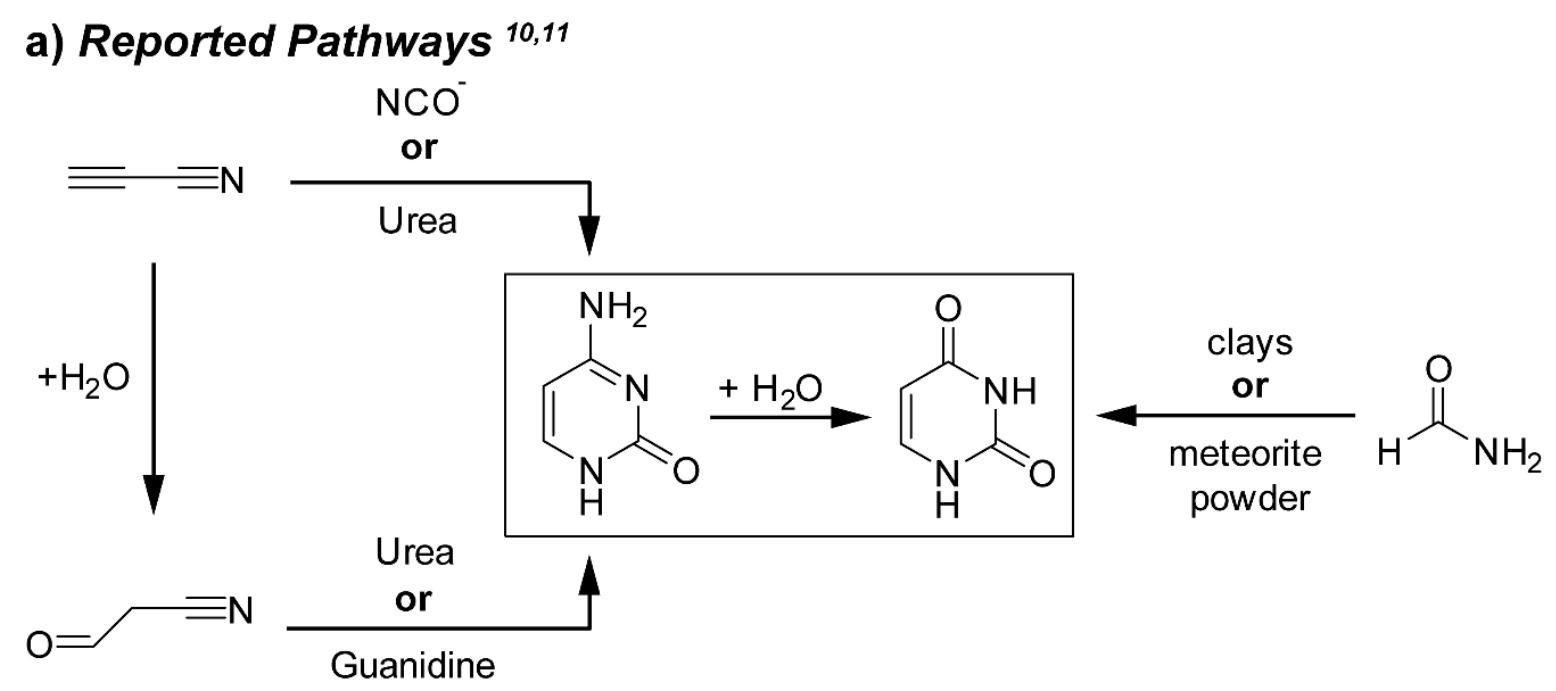

\section{b) New Pathway}

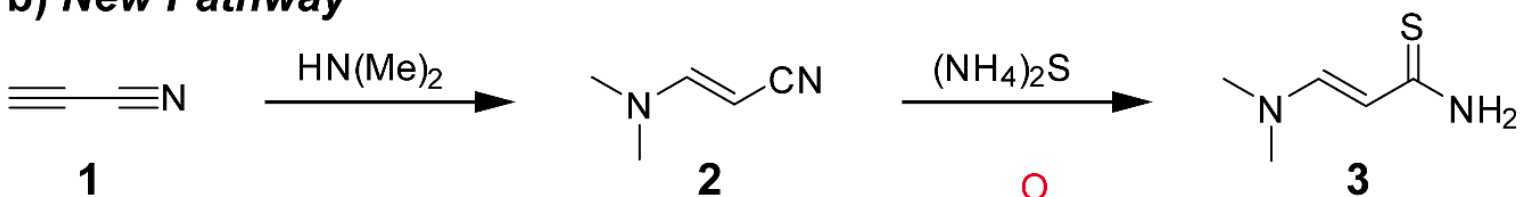

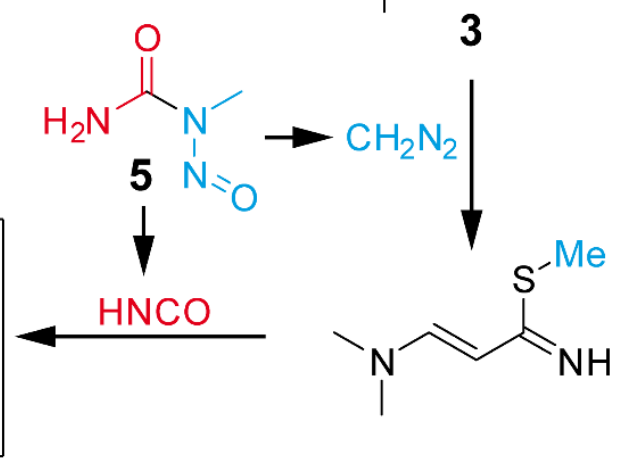<smiles>CSc1cc[nH]c(=O)n1</smiles><smiles>CSC(/C=C/N(C)C)=NC(N)=O</smiles>

\section{4}<smiles></smiles>

$7 a$<smiles>NCCNc1cc[nH]c(=O)n1</smiles>

7b<smiles>CC(C)CSC=C1C=CNC(=O)N1</smiles>

7c<smiles>CN(C)c1cc[nH]c(=O)n1</smiles>

7d<smiles>CN(C)c1cc[nH]c(=O)n1</smiles>

$7 e$

Fig. 1. (a) Previously reported pathway for pyrimidine nucleobase synthesis10,11 and (b) proposed pathway in this study. 
Here we report a new prebiotically plausible pathway to pyrimidines, which takes place in water. We discovered that cyanoacetylene 1 (Fig. 1) reacts quickly with dimethylamine. Both compounds were likely present on the early Earth. The reaction provides the stable acrylonitrile derivative $\mathbf{2}$, in which the reactivity of cyanoacetylene is captured. $\mathbf{2}$ is subsequently converted into a stable $\alpha, \beta$-unsaturated thioamide $\mathbf{3}$ upon sulfurization. Simultaneous methylation and carbamoylation of $\mathbf{3}$ gives carbamoylimidothioate $\mathbf{4}$, with spontaneous cyclization to the $S$ methylpyrimidinones (SMePy, 6) under basic conditions. Simultaneous methylation and carbamoylation under prebiotically plausible conditions is achieved with $\mathrm{N}$-methyl- $\mathrm{N}$ nitrosourea (MNU, 5). ${ }^{16}$

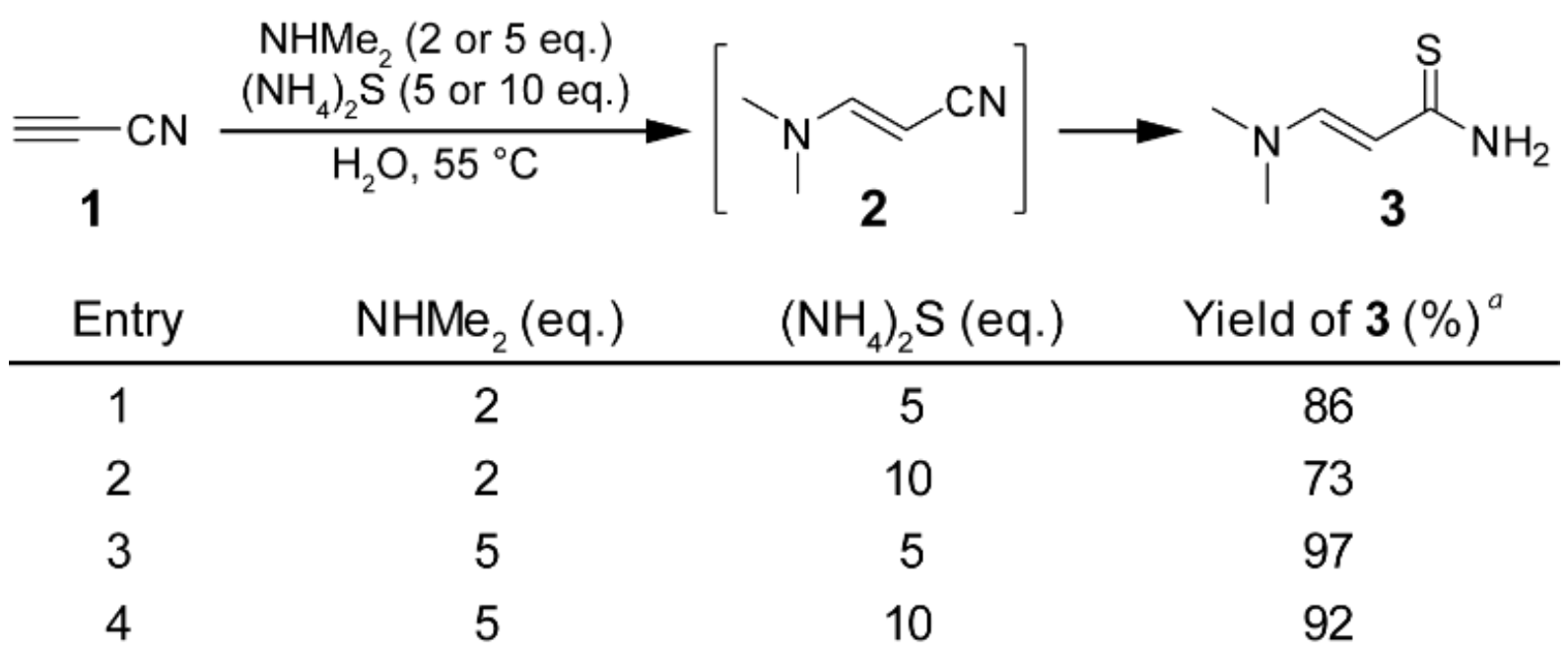

Table 1. Yields obtained under different reaction conditions for the conversion of $\mathbf{1}$ to $\mathbf{3} .{ }^{\mathrm{a}}$ Yields were determined by HPLC.

We first investigated the synthesis of $\alpha, \beta$-unsaturated thioamide 3 from cyanoacetylene 1 under prebiotically plausible conditions. Due to the electron-withdrawing nature of the nitrile group, the alkyne moiety of cyanoacetylene 1 is highly susceptible to a nucleophilic addition at its alkyne terminus. Indeed, upon addition to aqueous dimethylamine solution, 1 reacted immediately and quantitatively to form 3-(dimethylamino)acrylonitrile 2 (Scheme S1). Compound $\mathbf{2}$ was subsequently subjected to sulfurization. In initial attempts, we tested solutions of sodium hydrogen sulphide in phosphate, borate or carbonate buffer with different $\mathrm{pH}$ as a model solution of hydrogen sulphide. ${ }^{17}$ These conditions, however, gave only trace amount of the desired $\alpha, \beta$-unsaturated thioamide $\mathbf{3}$ (data not shown). We next turned our attention to ammonium sulphide as a prebiotically relevant sulfurization reagent. Ammonium sulphide is a salt of ammonia and hydrogen sulphide, both plausible prebiotic molecules. Ammonium sulphide is for example found in the atmosphere of Titan and Jupiter. ${ }^{18,19}$ When the acrylonitrile derivative $\mathbf{2}$ was reacted with different concentrations of ammonium sulphide in water at $55^{\circ} \mathrm{C}$, formation of the desired $\alpha, \beta$-unsaturated thioamide compound 3 was observed. Notably, it turned out that thioamide 3 (63\%) crystallized out from the reaction mixture upon cooling to room temperature, which can be considered to be a naturally occuring enrichment step by temperature change. 
We next examined if $\mathbf{3}$ can be formed in one-pot, despite the presence of competing nucleophiles. Cyanoacetylene $\mathbf{1}$ was slowly added to the solution containing different equivalents of dimethylamine and ammonium sulphide, and the reaction was gently heated to $55^{\circ} \mathrm{C}$ and analysed by reverse phase HPLC. The reaction provided thioamide 3 in high yields (up to $97 \%$, Table 1) showing that 1 reacts selectively with dimethylamine followed by capturing of the intermediate with $\left(\mathrm{NH}_{4}\right)_{2} \mathrm{~S}$.

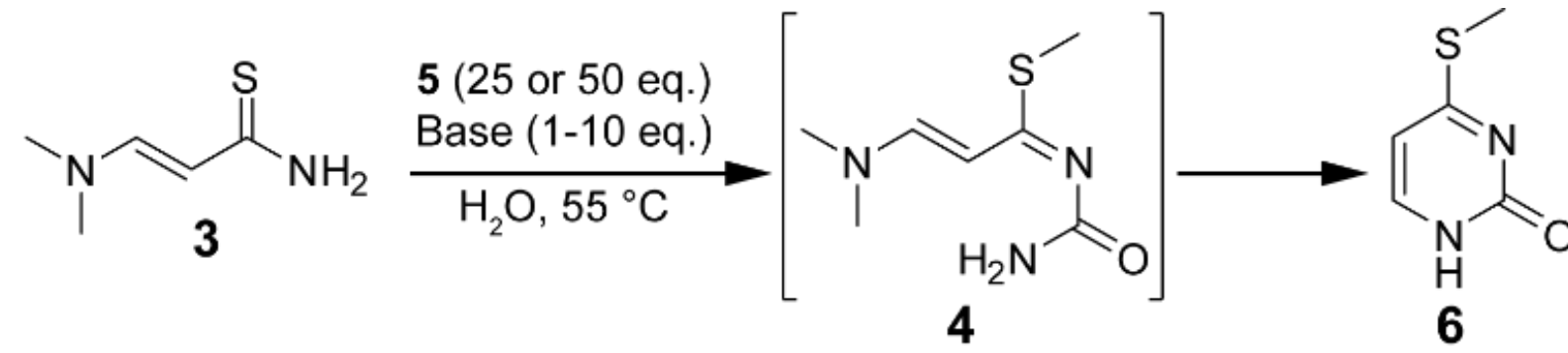

\begin{tabular}{cccc} 
Entry & Base (eq.) & $\mathbf{5}$ (eq.) & Yield of 6 \\
\hline 1 & $\mathrm{NaHCO}_{3}(10)$ & 25 & 15 \\
2 & $\mathrm{NaHCO}_{3}(10)$ & 50 & 22 \\
3 & Borax (1) & 25 & 8 \\
4 & Borax (1) & 50 & 18 \\
5 & $\left(\mathrm{NH}_{4}\right)_{2} \mathrm{~S}(3)$ & 25 & 11 \\
6 & $\left(\mathrm{NH}_{4}\right)_{2} \mathrm{~S}(3)$ & 50 & 17 \\
7 & $\mathrm{Na}_{2} \mathrm{HPO}_{4}(10)$ & 25 & 13 \\
8 & $\mathrm{Na}_{2} \mathrm{HPO}_{4}(10)$ & 50 & 18 \\
9 & $\mathrm{CaCO}_{3}(5)$ & 25 & 9 \\
10 & $\mathrm{CaCO}_{3}(5)$ & 50 & 13
\end{tabular}

Table 2. Yields obtained under different reaction conditions for the conversion of $\mathbf{3}$ to $\mathbf{6}$. ${ }^{\text {a }}$ Yields were determined by HPLC.

We further investigated the reaction of the so formed thioamide $\mathbf{3}$ with MNU $\mathbf{5}$ for the formation of SMePy $\mathbf{6}$. MNU $\mathbf{5}$ can be synthesized under plausible prebiotic conditions by reacting $\mathbf{N}$-methylurea with sodium nitrite in a slightly acidic environment. MNU $\mathbf{5}$ separates spontaneously from the water solution, allowing it to be locally available in high quantities. It is known that MNU produces diazomethane and isocyanic acid under basic conditions or by thermal degradation. ${ }^{20}$ Accordingly, we assumed that MNU would operate as a bifunctional reagent. We expected that the carbamoylimidothioate 4 , which is formed by the methylation of thiocarbonyl group of thioamide $\mathbf{3}$ with diazomethane would undergo carbamoylation with isocyanic acid, followed by a base-catalysed cyclization to build up the pyrimidine skeleton. For this, MNU 5 was added to the solution containing thioamide $\mathbf{3}$ and sodium bicarbonate under mild heating at $55^{\circ} \mathrm{C}$. The reaction was monitored by HPLC (Fig. S2a). The newly present peak was isolated and analysed by ${ }^{1} \mathrm{H}-\mathrm{NMR}$, confirming formation of the desired SMePy 6 . We did 
not observe the carbamoylimidothioate 4 in the HPLC chromatogram, presumably because it cyclizes immediately to SMePy 6 after the carbamoylation reaction. The yield of SMePy 6 was determined to be $22 \%$ by HPLC-MS based on the calibration curve that was prepared using a chemically synthesized reference compound. ${ }^{21}$

The reaction was further investigated regarding its sensitivity to the presence of different prebiotically relevant bases and minerals. The data are summarized in Table 2 and Fig. S2. All tested conditions gave similar yields of SMePy 6, showing that the reaction is robust, which is one of our main criteria for calling a reaction prebiotically plausible. More importantly, formation of SMePy 6 was observed in the presence of the ammonium sulphide under conditions also utilized for the formation of thioamide 3. This observation led to the idea to conduct a one-pot synthesis of the SMePy 6, a precursor of canonical and non-canonical pyrimidine nucleobases.

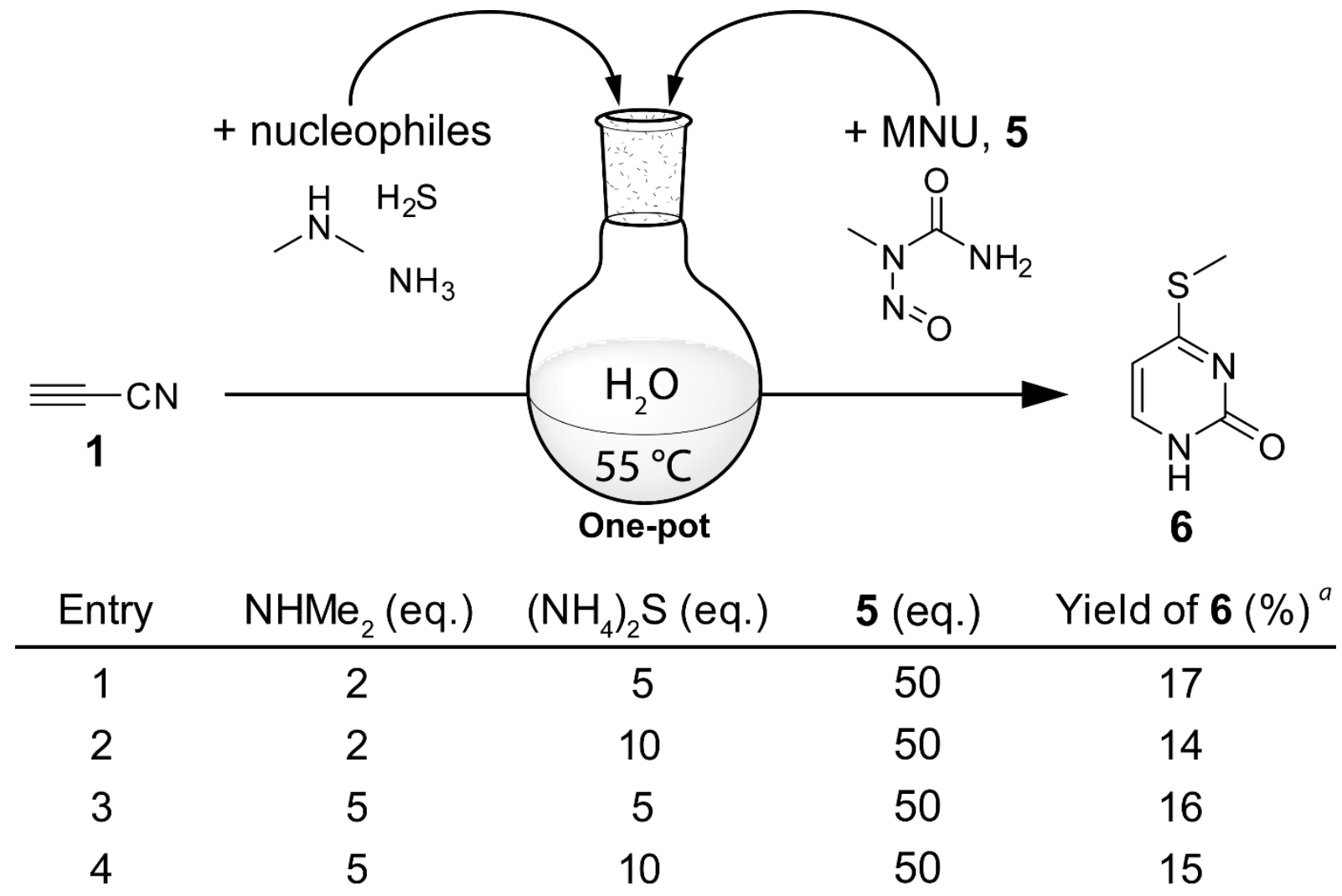

Figure 2. One-pot synthesis of SMePy 6 in the presence of different equivalents of the reagents. ${ }^{a}$ Yields were determined by HPLC.

To achieve a one-pot synthesis of 6 (Fig. 2), cyanoacetylene 1 was first reacted with a dimethylamine solution containing ammonium sulphide in different amounts. After warming the reaction to $55^{\circ} \mathrm{C}$ for $24 \mathrm{hrs}$, the reaction mixture was diluted with water and MNU 5 was added. The reaction mixture was again warmed to $55^{\circ} \mathrm{C}$ for another $24 \mathrm{hrs}$ and finally analysed by reverse phase HPLC. The desired SMePy 6 was obtained in $14-17 \%$ yield over three steps under these one-pot conditions.

Finally, we investigated the conversion of SMePy 6 to canonical nucleobases under plausible prebiotic conditions (Table 3). The conversion of SMePy 6 into uracil 7a can be catalysed by $\mathrm{Fe}^{2+}$. Heating SMePy 6 in aqueous solution containing $\mathrm{FeSO}_{4}$, provided 7a quantitatively. $\mathrm{FeSO}_{4}$ is naturally available from minerals such as Rozenite and Melanterite. ${ }^{22}$ Cytosine $\mathbf{7 b}$ was in contrast obtained by heating SMePy 6 in aqueous ammonia solution in the presence of $\mathrm{FeSO}_{4}$. 
This demonstrates an efficient "mineral guided" formation of the canonical pyrimidine bases. Furthermore, reaction of 6 with ammonium sulphide furnished 4-thiouracil 7c, another wellknown modification present in the tRNA of bacteria and archaea. ${ }^{23}$ Interestingly, the concentration of ammonium sulphide determines the outcome of this reaction, while either cytosine or 4-thiouracil is formed (Table 3 ). Since cytosine hydrolysed slowly to uracil, the ammonium sulphide conditions provide cytosine, uracil and 4-thiouracil simultaneously. Finally, we investigated whether also non-canonical bases can form from SMePy 6 . Such bases are present in contemporary RNA as constituents to modify structural and functional features. ${ }^{6}$ If they would form under identical conditions, this would strengthen our hypothesis that canonical and non-canonical bases emerged simultaneously as competitor and companion molecules that found their roles in a subsequent chemical selection process. ${ }^{16,17,24-26}$ In order to investigate this possibility we reacted SMePy 6 with different amines in aqueous solutions. Upon treatment with methylamine and dimethylamine, 4-mono- and 4-dimethylcytosine (7d and 7e) were obtained respectively, which are indeed found as modified bases in contemporary RNA species. ${ }^{27}$

7a

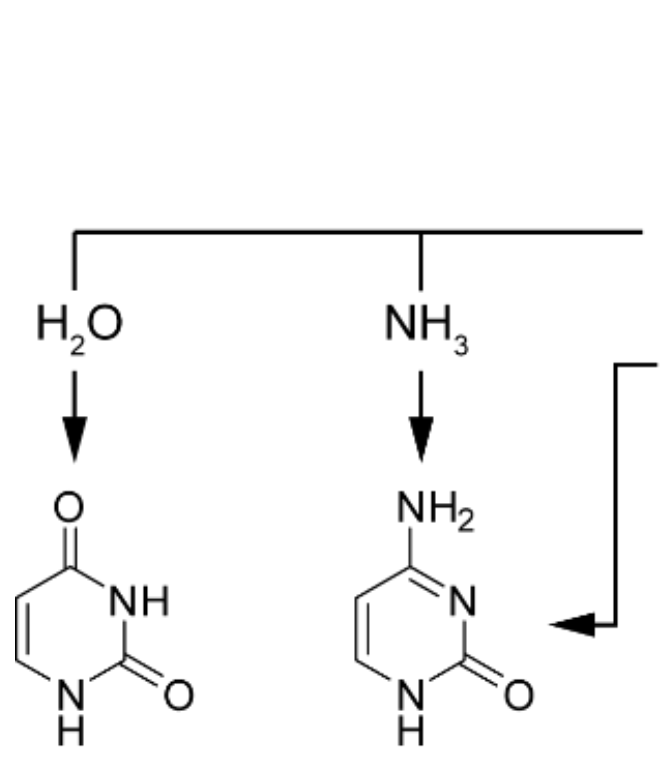

$7 \mathrm{~b}$<smiles>CSc1cc[nH]c(=O)n1</smiles>

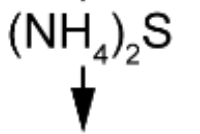<smiles></smiles>

7c<smiles>CN(C)CCN(C)c1cc[nH]c(=O)n1</smiles>

$7 d$
$7 e$

\begin{tabular}{cccc} 
Entry & Nucleophile (\%) & $\mathrm{FeSO}_{4}$ (eq.) & Product (yield in \%) \\
\hline 1 & $\mathrm{H}_{2} \mathrm{O}$ & 1 & $\mathbf{7 a}$ (quant.) \\
2 & $\mathrm{NH}_{3}(5)$ & 1 & $\mathbf{7 b}(77)^{a}$ \\
3 & $\left(\mathrm{NH}_{4}\right)_{2} \mathrm{~S}(1)$ & - & $\mathbf{7 b}(5) / \mathbf{c c}(80)^{b}$ \\
4 & $\left(\mathrm{NH}_{4}\right)_{2} \mathrm{~S}(5)$ & - & $\mathbf{7 b}(21) / \mathbf{7 c}(0)^{b}$ \\
5 & $\left(\mathrm{NH}_{4}\right)_{2} \mathrm{~S}(10)$ & - & $\mathbf{7 b}(43) / 7 \mathbf{c}(0)^{b}$ \\
6 & $\mathrm{NH}_{2} \mathrm{Me}(1)$ & - & $\mathbf{7 d ~}(70)^{b}$ \\
7 & $\mathrm{NHMe}_{2}(1)$ & - & $\mathbf{7 e ~}(95)^{b}$
\end{tabular}

Table 3. Conversion yields of 6 to 4 -substituted pyrimidines with different nucleophiles. ${ }^{a}$ Isolated yield.

${ }^{b}$ Yields were determined by HPLC. 
In summary, we discovered a new plausible prebiotic pathway, which takes place in continuous manner in water. The process provides canonical as well as C4-modified pyrimidine nucleobases. Although cyanoacetylene has been widely investigated as the building block of nucleobases and nucleosides, its high-electrophilic character has always questioned its involvement. Here we show that one can start the pyrimidine synthesis with a trapped version of cyanoacetylene, namely the stable acrylonitrile derivative. We show that the cascade reaction proceeds under one-pot conditions in a continuous manner to provide SMePy 6 . Importantly the key intermediate SMePy $\mathbf{6}$ gives rise not only to canonical but also to noncanonical bases arguing for the simultaneous prebiotic formation of a diverse set of pyrimidines under prebiotically plausible conditions.

\section{Conflicts of interest}

The authors declare no conflicts of interest.

\section{Acknowledgement}

This study was supported by the Deutsche Forschungsgemeinschaft (DFG) for financial support via the programs SFB1032 (TP-A5), SFB749 (TP-A4), SPP-1784, CA275/11-1. Additional funding from the Excellence Cluster EXC117 CiPSM is acknowledged. This project has received funding from the European Research Council (ERC) under the European Union's Horizon 2020 research and innovation programme (Project ID: 741912). H.O. received a Marie Sklodowska-Curie Individual Fellowship (Project ID: 752420) from the European Commission.

\section{Notes and references}

1 K. Kruger, P. J. Grabowski, A. J. Zaug, J. Sands, D. E. Gottschling and T. R. Cech, Cell, 1982, 31, 147-157.

2 C. Guerrier-Takada, K. Gardiner, T. Marsh, N. Pace and S. Altman, Cell, 1983, 35, 849-857.

3 W. Gilbert, Nature, 1986, 319, 618-618.

4 T. A. Lincoln and G. F. Joyce, Science, 2009, 323, 1229-1232.

5 J. Attwater, A. Raguram, A. S. Morgunov, E. Gianni and P. Holliger, Elife, 2018, 7, e35255.

6 T. Carell, C. Brandmayr, A. Hienzsch, M. Müller, D. Pearson, V. Reiter, I. Thoma, P. Thumbs and M. Wagner, Angew. Chem. Int. Ed., 2012, 51, 7110-7131.

7 S. J. Sowerby and W. M. Heckl, Orig. Life Evol. Biosph., 1998, 28, 283-310.

8 T. Kawasaki, Y. Hakoda, H. Mineki, K. Suzuki and K. Soai, J. Am. Chem. Soc., 2010, 132, 2874-2875.

9 R. A. Black, M. C. Blosser, B. L. Stottrup, R. Tavakley, D. W. Deamer and S. L. Keller, Proc. Natl. Acad. Sci. U. S. A., 2013, 110, 13272-6.

10 J. P. Ferris, R. A. Sanchez and L. E. Orgel, J. Mol. Biol., 1968, 33, 693-704.

11 M. P. Robertson and S. L. Miller, Nature, 1995, 375, 772-774.

12 L. E. Orgel, Orig. Life Evol. Biosph., 2002, 32, 279-281.

13 C. Menor-Salván, D. M. Ruiz-Bermejo, M. I. Guzmán, S. Osuna-Esteban and S. VeintemillasVerdaguer, Chem. Eur. J., 2009, 15, 4411-4418.

14 D. Niether, D. Afanasenkau, J. K. G. Dhont and S. Wiegand, Proc. Natl. Acad. Sci. U. S. A., 2016, 113, 4272-7.

15 M. Ferus, F. Pietrucci, A. M. Saitta, A. Knížek, P. Kubelík, O. Ivanek, V. Shestivska and S. Civiš, Proc. Natl. Acad. Sci. U. S. A., 2017, 114, 4306-4311. 
16 C. Schneider, S. Becker, H. Okamura, A. Crisp, T. Amatov, M. Stadlmeier and T. Carell, Angew. Chem. Int. Ed., 2018, 57, 5943-5946.

17 S. Stairs, A. Nikmal, D.-K. Bučar, S.-L. Zheng, J. W. Szostak and M. W. Powner, Nat. Commun., 2017, 8, 15270.

18 E. Karkoschka, Icarus, 1998, 133, 134-146.

19 M. J. Loeffler, R. L. Hudson, N. J. Chanover and A. A. Simon, Icarus, 2016, 271, 265-268.

20 B. T. Golding, C. Bleasdale, J. McGinnis, S. Müller, H. T. Rees, N. H. Rees, P. B. Farmer and W. P. Watson, Tetrahedron, 1997, 53, 4063-4082.

21 T. J. Delia, M. J. Olsen and G. B. Brown, J. Org. Chem., 1965, 30, 2766-2768.

22 J. L. Jambor, D. K. Nordstrom and C. N. Alpers, Rev. Mineral. Geochem., 2000, 40, 303-350.

23 Y. Liu, X. Zhu, A. Nakamura, R. Orlando, D. Söll and W. B. Whitman, J. Biol. Chem., 2012, 287, 36683-92.

24 M. Levy and S. L. Miller, J. Mol. Evol., 1999, 48, 631-637.

25 S. Becker, I. Thoma, A. Deutsch, T. Gehrke, P. Mayer, H. Zipse and T. Carell, Science, 2016, 352, 833-6.

26 S. Becker, C. Schneider, H. Okamura, A. Crisp, T. Amatov, M. Dejmek and T. Carell, Nat. Commun., 2018, 9, 163.

27 P. A. Limbach, P. F. Crain and J. A. McCloskey, Nucleic Acids Res., 1994, 22, 2183-2196. 


\title{
Supporting information
}

\section{A one-pot, water compatible synthesis of pyrimidine nucleobases under plausible prebiotic conditions}

\author{
Hidenori Okamura, Sidney Becker, Niklas Tiede, \\ Stefan Wiedemann, Jonas Feldmann and Thomas Carell* \\ Center for Integrated Protein Science (CiPSM) at the Department of Chemistry \\ Ludwig-Maximilians-Universität München, Butenandtstr. 5-13, 81377 München, Germany \\ E-mail: thomas.carell@lmu.de
}

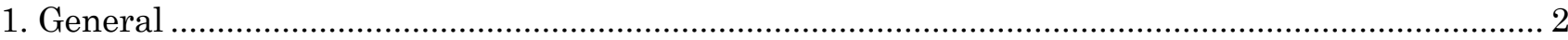

2. A stepwise synthesis of thioamide 3 under plausible prebiotic conditions...................................... 3

3. One-pot synthesis of thioamide 3 under plausible prebiotic conditions ....................................... 4

4. Synthesis of SMePy 6 under plausible prebiotic conditions .......................................................... 5

5. One-pot synthesis of SMePy 6 under plausible prebiotic conditions ….......................................... 7

6. Conversion of SMePy 6 into 4-substituted pyrimidine nucleobases ................................................ 8

7. Calibration curves of the compounds synthesized in this study ................................................ 11

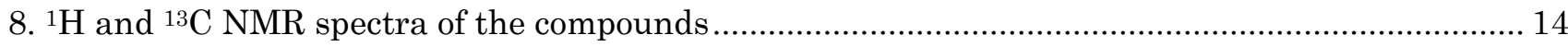

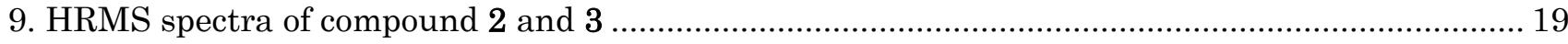

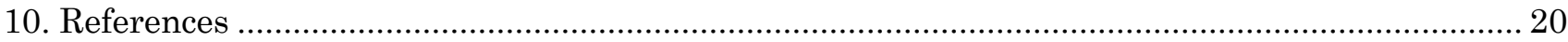




\section{General}

Chemicals were purchased from Sigma-Aldrich, TCI, Fluka, ABCR, Carbosynth or Acros organics and used further purification. The solvents were of reagent grade or purified by distillation. Reactions and chromatography fractions were monitored by qualitative thin-layer chromatography (TLC) on silica gel $\mathrm{F}_{254}$ TLC plates from Merck KGaA. Flash column chromatography was performed on Geduran ${ }^{\circledR}$ Si60 $(40-63 \mu \mathrm{m})$ silica gel from Merck KGaA. NMR spectra were recorded on Bruker AVIIIHD 400 spectrometers $(400 \mathrm{MHz}),{ }^{1} \mathrm{H}$ NMR shifts were calibrated to the residual solvent resonances: $\mathrm{CDCl}_{3}(7.26 \mathrm{ppm}), \mathrm{DMSO}_{-} d_{6}(2.50 \mathrm{ppm}), \mathrm{CD}_{3} \mathrm{OD}(4.87 \mathrm{ppm}), \mathrm{D}_{2} \mathrm{O}(4.79 \mathrm{ppm}) .{ }^{13} \mathrm{C} \mathrm{NMR}$ shifts were calibrated to the residual solvent: $\mathrm{CDCl}_{3}(77.16 \mathrm{ppm}), \mathrm{DMSO}-d_{6}(39.52 \mathrm{ppm}), \mathrm{CD}_{3} \mathrm{OD}$ (49.00 ppm). All NMR spectra were analyzed using the program MestRE NOVA 10.0.1 from Mestrelab Research S. L. Normal resolved mass spectra were measured on a LTQ FT-ICR by Thermo Finnigan GmbH. High resolution mass spectra were measured by the analytical section of the Department of Chemistry of the Ludwigs-Maximilians-Universität München on the following spectrometers (ionization mode in brackets): MAT 95 (EI) and MAT 90 (ESI) from Thermo Finnigan GmbH. IR spectra were recorded on a PerkinElmer Spectrum BX II FT-IR system. All substances were directly applied as solids or on the ATR unit. Analytical RP-HPLC was performed on an analytical HPLC Waters Alliance (2695 Separation Module, 2996 Photodiode Array Detector) equipped with the column Nucleosil 120-2 C18 from Macherey Nagel using a flow of $0.5 \mathrm{ml} / \mathrm{min}$, a gradient of $0-70 \%$ of buffer B in 30 min was applied for the measurements. Preparative RP-HPLC was performed on a HPLC Waters Breeze (2487 Dual A Array Detector, 1525 Binary HPLC Pump) equipped with the column VP 250/32 C18 from Macherey Nagel. Using a flow of $5 \mathrm{ml} / \mathrm{min}$, a gradient of $0-70 \%$ of buffer B in 30 min was applied for the purifications. Buffer A: $50 \mathrm{mM}$ ammonium formate in $\mathrm{H}_{2} \mathrm{O}$, Buffer B: $50 \mathrm{mM}$ ammonium formate in $80 \%(\mathrm{v} / \mathrm{v})$ acetonitrile. Detection wavelength: 260 $\mathrm{nm}$. 
2. A stepwise synthesis of thioamide 3 under plausible prebiotic conditions

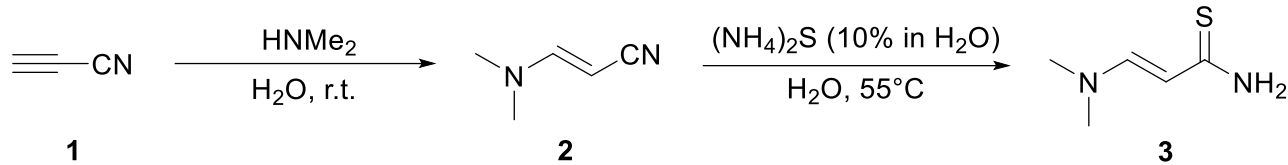

Scheme S1. A stepwise synthesis of thioamide $\mathbf{3}$ from cyanoacetylene $\mathbf{1}$

\section{3-(Dimethylamino)acrylonitrile (2)}

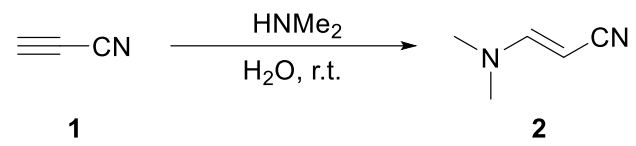

To a solution of dimethylamine $\left(405 \mu \mathrm{l}, 40 \%\right.$ in $\left.\mathrm{H}_{2} \mathrm{O}, 3.19 \mathrm{mmol}\right)$ in $\mathrm{H}_{2} \mathrm{O}(16 \mathrm{ml})$ was added cyanoacetylene $1(100 \mu \mathrm{l}, 1.60 \mathrm{mmol})$ at room temperature. After $20 \mathrm{~h}$, the colorless solution was extracted with $\mathrm{CH}_{2} \mathrm{Cl}_{2}$. The combined organic phase was washed with brine and dried over $\mathrm{MgSO}_{4}$. The solvent was removed under reduced pressure to yield the compound 2 (140 mg, $1.50 \mathrm{mmol}, 94 \%)$ as a colorless oil. The spectra data matched with the compound 2 purchased from TCI Germany (product number: D2094).

IR (neat, cm $\left.{ }^{-1}\right) 3077(\mathrm{w}), 2915(\mathrm{w}), 2818(\mathrm{w}), 2189(\mathrm{~s}), 1623(\mathrm{~s}), 1485(\mathrm{w}), 1437(\mathrm{~m}), 1420(\mathrm{w}), 1391(\mathrm{~s})$, $1346(\mathrm{~m}), 1287(\mathrm{~m}), 1214(\mathrm{w}), 1114(\mathrm{~m}), 1066(\mathrm{~m}), 1023(\mathrm{w}), 957(\mathrm{~m}), 862(\mathrm{w}), 709(\mathrm{~m}),{ }^{1} \mathrm{H}$ NMR $(400$ MHz, DMSO- $\left.d_{6}\right) \delta 7.21(\mathrm{~d}, J=13.4 \mathrm{~Hz}, 1 \mathrm{H}), 3.82(\mathrm{~d}, J=13.5 \mathrm{~Hz}, 1 \mathrm{H}), 2.89(\mathrm{br}, 3 \mathrm{H}), 2.70(\mathrm{br}, 3 \mathrm{H}),{ }^{13} \mathrm{C}$ NMR (100 MHz, DMSO- $\left.d_{6}\right) \delta$ 155.1, 122.7, 58.3, HRMS (EI) calcd. for $\mathrm{C}_{5} \mathrm{H}_{8} \mathrm{~N}_{2}+[\mathrm{M}]+:$ 96.0687, found: 96.0683.

\section{3-(Dimethylamino)prop-2-enethioamide (3)}

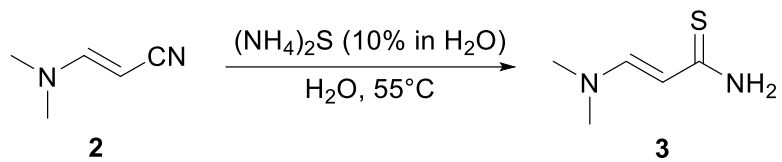

To a solution of $\left(\mathrm{NH}_{4}\right)_{2} \mathrm{~S}\left(20 \mathrm{ml}, 20 \%\right.$ in $\left.\mathrm{H}_{2} \mathrm{O}, \mathrm{mmol}\right)$ in $\mathrm{H}_{2} \mathrm{O}(20 \mathrm{ml})$ was added compound $2(2 \mathrm{ml}$, $19.76 \mathrm{mmol}$ ), and the reaction mixture was stirred at $55^{\circ} \mathrm{C}$. After $12 \mathrm{~h}$, the reaction mixture was cooled to room temperature. The compound 3 crystallized out from the reaction mixture as a yellow solid (1.63 g, $12.51 \mathrm{mmol}, 63 \%)$.

IR (neat, cm-1) $3337(\mathrm{w}), 3268(\mathrm{w}), 3158(\mathrm{~m}), 1600(\mathrm{~s}), 1495(\mathrm{w}), 1428(\mathrm{~m}), 1372(\mathrm{~m}), 1342(\mathrm{~m}), 1310$ $(\mathrm{m}), 1278(\mathrm{~s}), 1114(\mathrm{~s}), 1038(\mathrm{~s}), 980(\mathrm{~s}), 861(\mathrm{~s}), 810(\mathrm{~s}), 670(\mathrm{~m}),{ }^{1} \mathrm{H}$ NMR (400 MHz, DMSO- $\left.d_{6}\right) \delta 8.01$ (br, $1 \mathrm{H}), 7.86(\mathrm{br}, 1 \mathrm{H}), 7.70(\mathrm{~d}, J=12.2 \mathrm{~Hz}, 1 \mathrm{H}), 5.20(\mathrm{~d}, J=12.2 \mathrm{~Hz}, 1 \mathrm{H}), 2.88(\mathrm{~s}, 6 \mathrm{H}),{ }^{13 \mathrm{C}} \mathrm{NMR}(100$ MHz, DMSO- $\left.d_{6}\right) \delta 194.6,155.3$, 96.5, HRMS (EI) calcd. for $\mathrm{C}_{5} \mathrm{H}_{10} \mathrm{~N}_{2} \mathrm{~S}^{+}[\mathrm{M}]+$ : 130.0565 , found: 130.0560 . 
3. One-pot synthesis of thioamide 3 under plausible prebiotic conditions

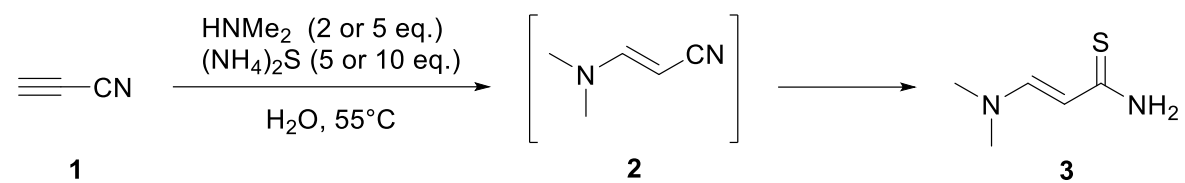

Cyanoacetylene $1(20 \mu \mathrm{l}, 0.32 \mathrm{mmol})$ was added to a solution of dimethylamine $\left(40 \%\right.$ in $\mathrm{H}_{2} \mathrm{O}, 2$ or 5 eq.) and ammonium sulfide $\left(20 \%\right.$ in $\mathrm{H}_{2} \mathrm{O}, 5$ or 10 eq.) in $\mathrm{H}_{2} \mathrm{O}(2 \mathrm{ml})$ at room temperature, and the reaction mixture was shaken at $55^{\circ} \mathrm{C}$ for $24 \mathrm{~h}$ in a thermomixer. The reaction was monitored by HPLC (Fig. S1). The product peak (compound 3; Retention time: $12.8 \mathrm{~min}$ ) was isolated and analyzed by NMR measurement by which the structural integrity was confirmed. The yield of the compound 3 from each reaction was determined according to the calibration curve prepared from the synthetically prepared compound 3 (Fig. S5a).(1)
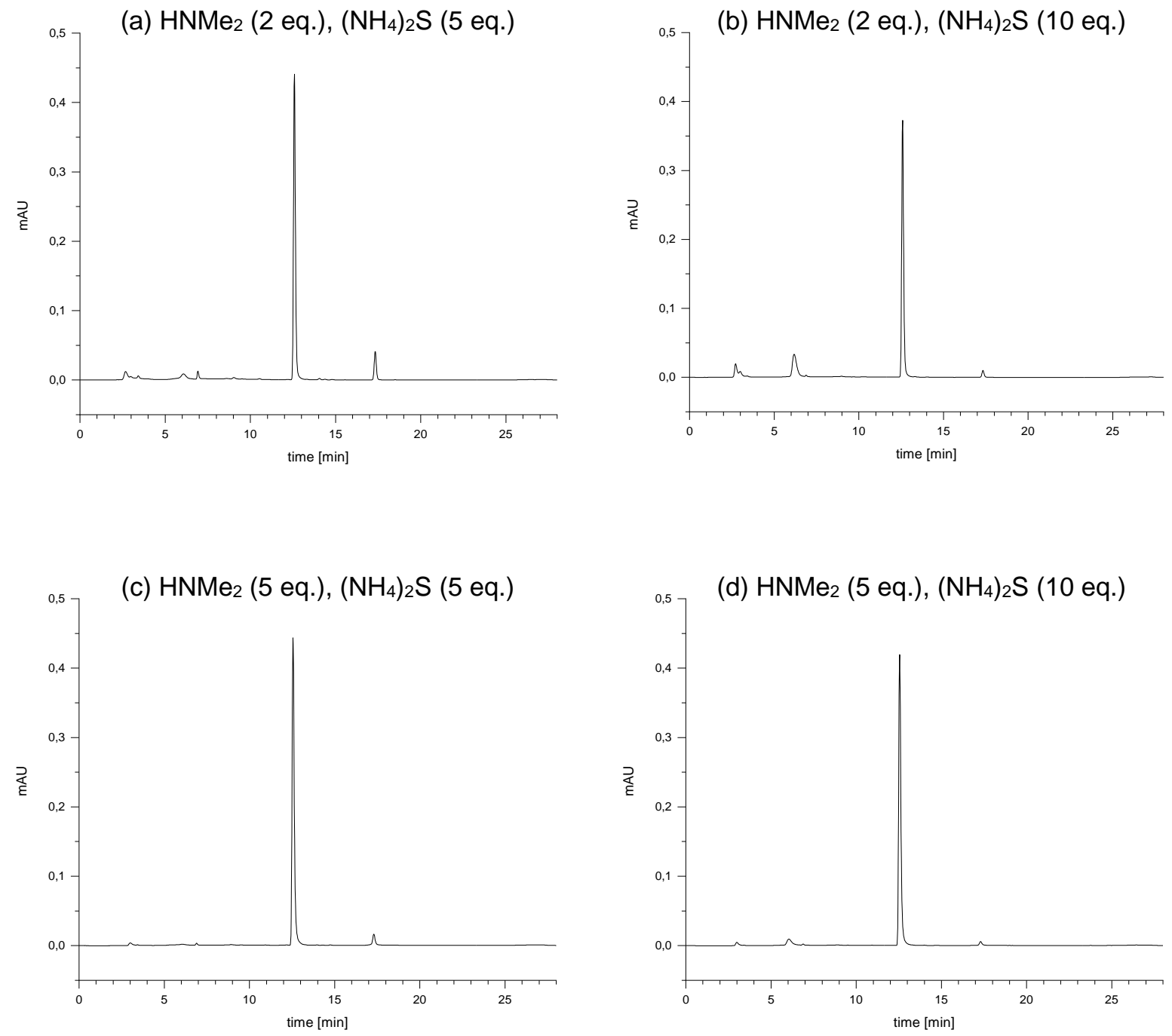

Figure S1. HPLC analysis of the one-pot thioamide 3 syntheses in different equivalents of the reagents. 
4. Synthesis of SMePy 6 under plausible prebiotic conditions

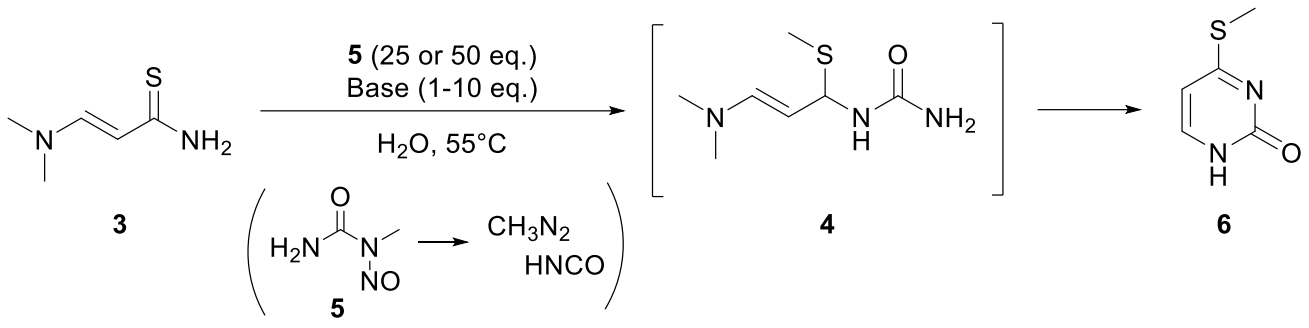

To a solution of compound $3(2 \mathrm{mg}, \mathrm{mmol})$ in $\mathrm{H}_{2} \mathrm{O}(1 \mathrm{ml})$ was added base $(1 \sim 10$ eq. $)$ and $N$-methyl- $N$-nitrosourea $5^{(2)}\left(25\right.$ or 50 eq.), and the reaction mixture was shaken at $55^{\circ} \mathrm{C}$ for $24 \mathrm{~h}$ in a thermomixer. The reaction was monitored by HPLC (Fig. S2). The product peak (compound 6; Retention time: $13.2 \mathrm{~min}$ ) was isolated and analyzed by NMR measurement by which the structural integrity was confirmed. The yield of the compound 6 from each reaction was determined according to the calibration curve prepared from the synthetically prepared compound 6 (Fig. S5b).(3)
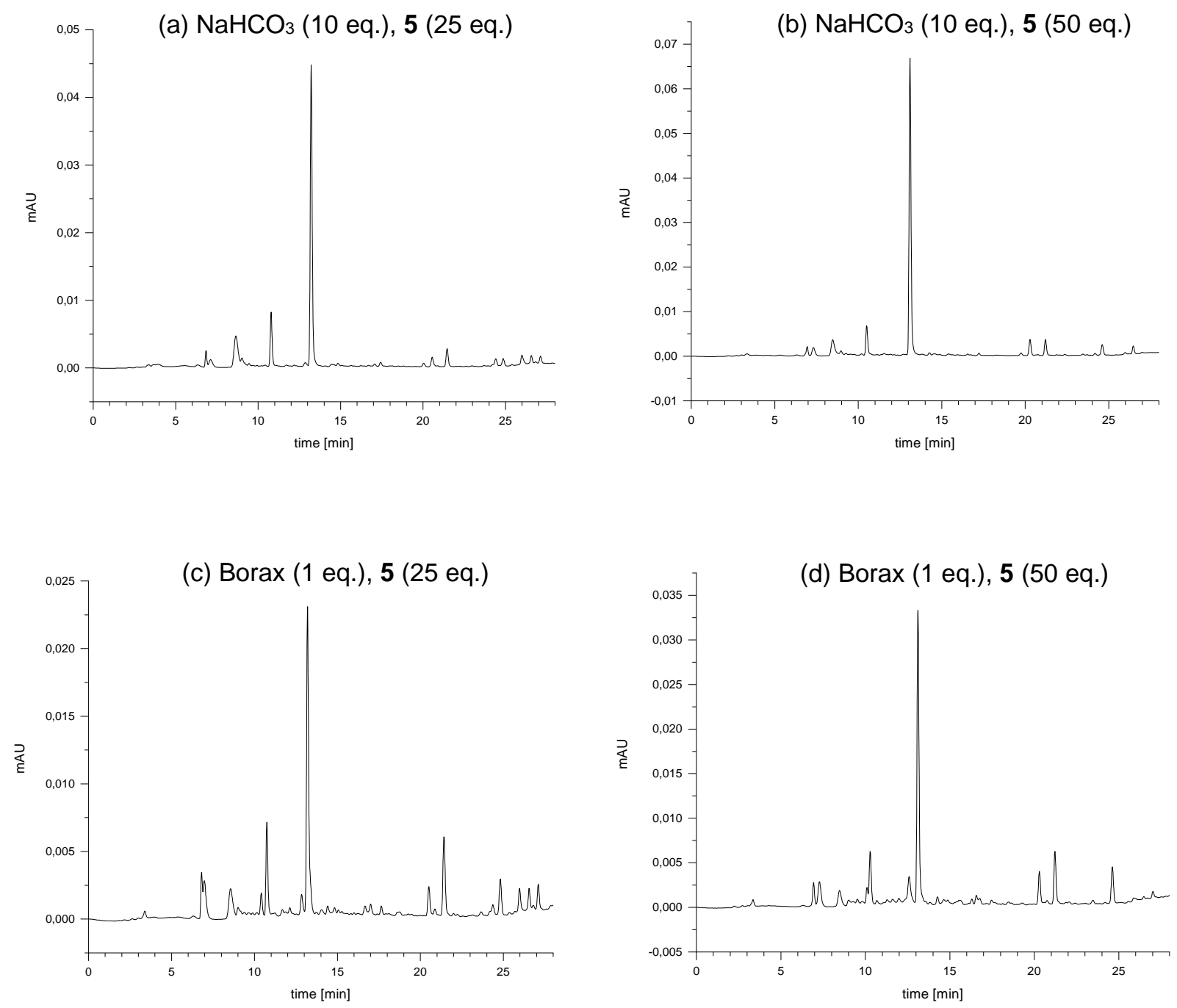

Figure S2. HPLC analysis of the SMePy 6 syntheses in the presence of different kinds of bases. 

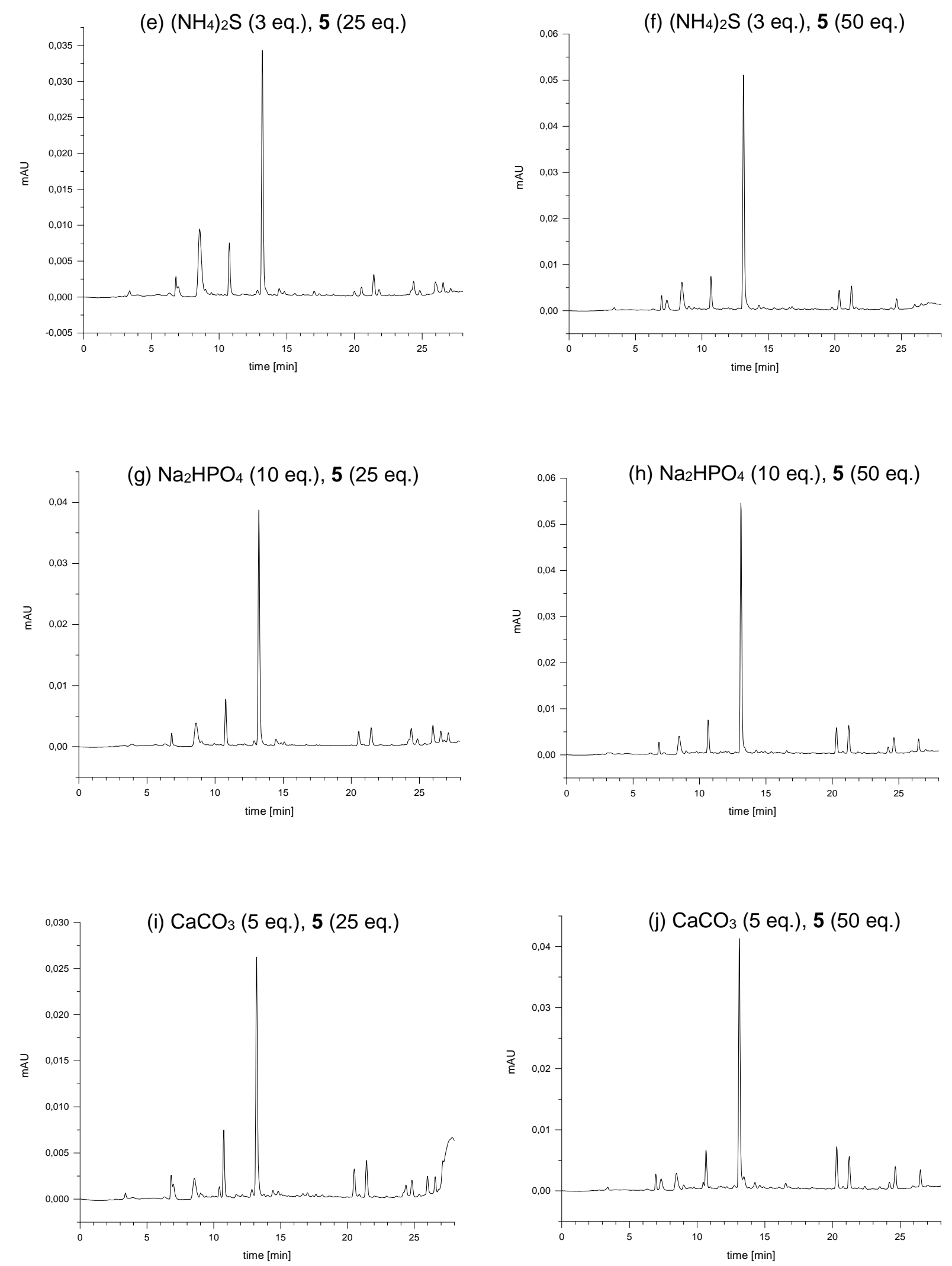

Figure S2 (continued). HPLC analysis of the SMePy 6 syntheses in the presence of different kinds of bases. 
5. One-pot synthesis of SMePy 6 under plausible prebiotic conditions
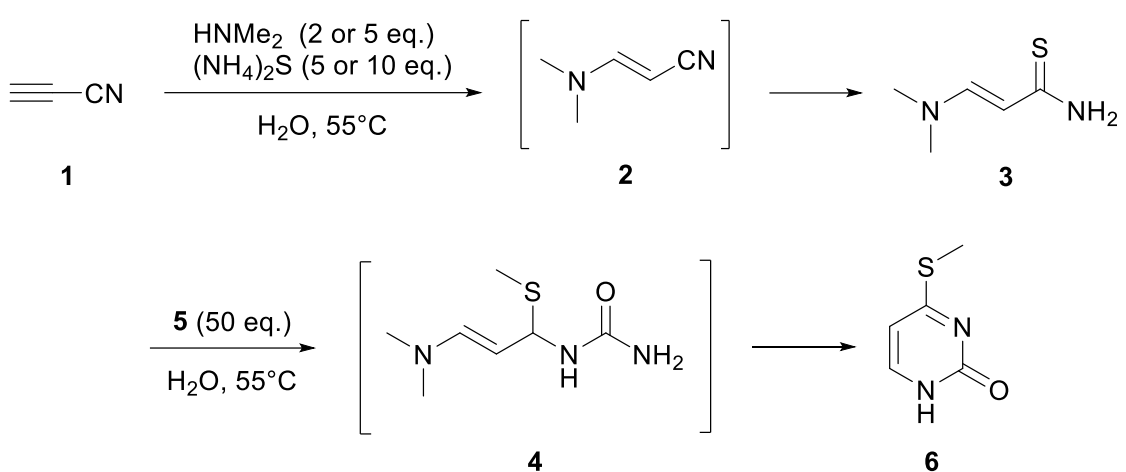

Cyanoacetylene $(20 \mu \mathrm{l}, 0.32 \mathrm{mmol})$ was added to a solution of dimethylamine $\left(40 \%\right.$ in $\mathrm{H}_{2} \mathrm{O}, 2$ or 5 eq.) and ammonium sulfide ( $20 \%$ in $\mathrm{H}_{2} \mathrm{O}, 5$ or 10 eq.) in $\mathrm{H}_{2} \mathrm{O}(2 \mathrm{ml})$ and samples were shaken at $55^{\circ} \mathrm{C}$ for $24 \mathrm{~h}$. The solutions were made up to $16 \mathrm{ml}$ with $\mathrm{H}_{2} \mathrm{O}$ to dissolve precipitate completely, and $1 \mathrm{ml}$ of the solution was transferred into a new falcon tube. $N$-methyl- $N$-nitrosourea 5 (50 eq.) was added and the suspension was shaken at $55^{\circ} \mathrm{C}$ in a thermomixer for $24 \mathrm{~h}$. The reaction was monitored by HPLC (Fig. S3). The yield of the compound 6 (Retention time: $13.2 \mathrm{~min}$ ) from each reaction was determined according to the calibration curve (Fig. S5b).
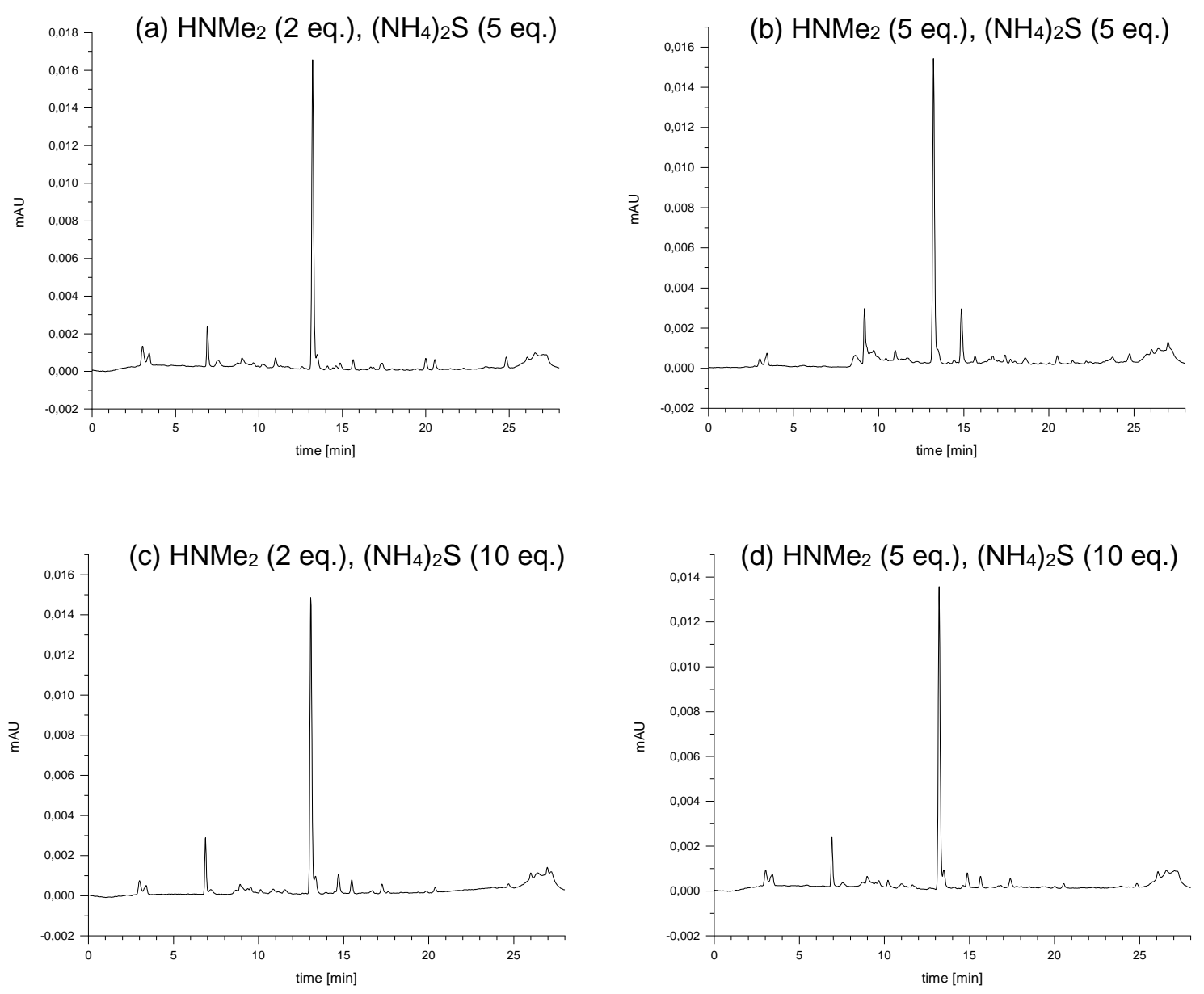

Figure S3. HPLC analysis of SMePy 6 syntheses in one-pot in different equivalents of the reagents. 


\section{Uracil (7a)}

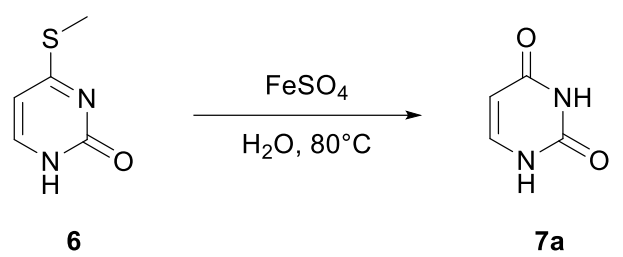

Compound $6(10 \mathrm{mg}, 70 \mu \mathrm{mol})$ was added to a solution of $\mathrm{FeSO}_{4}-7 \mathrm{H}_{2} \mathrm{O}(19.6 \mathrm{mg}, 70 \mu \mathrm{mol})$ in $\mathrm{H}_{2} \mathrm{O}$ $(5 \mathrm{ml})$ and the reaction mixture was stirred at $80^{\circ} \mathrm{C}$. After 3 days, the reaction mixture was lyophilized. Purification of the crude product by flash column chromatography $\left(\mathrm{CH}_{2} \mathrm{Cl}_{2}: \mathrm{MeOH}=\right.$ 90:10 to 80:20) yielded compound 7 a $(7.8 \mathrm{mg}, 69 \mathrm{\mu mol}$, quant.) as a colorless solid. The analytical data matched those reported previously. ${ }^{(4)}$

\section{Cytosine (7b)}

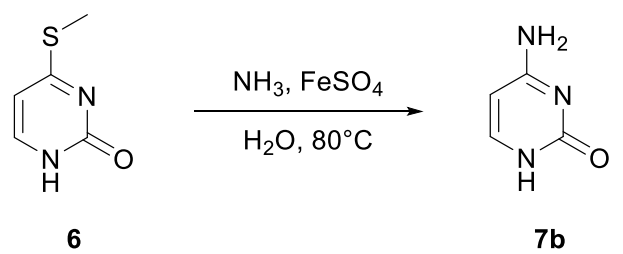

Compound $6(10 \mathrm{mg}, 70 \mu \mathrm{mol})$ was added to a solution of $\mathrm{FeSO}_{4^{-}} 7 \mathrm{H}_{2} \mathrm{O}(19.6 \mathrm{mg}, 70 \mu \mathrm{mol})$ in $\mathrm{H}_{2} \mathrm{O}$ $(2.6 \mathrm{ml})$ and ammonia solution $\left(28 \%\right.$ in $\left.\mathrm{H}_{2} \mathrm{O}, 1.7 \mathrm{ml}\right)$ and the reaction mixture was stirred at $80^{\circ} \mathrm{C}$. After 3 days, the reaction mixture was freeze dried. Purification of the crude product by flash column chromatography $\left(\mathrm{CH}_{2} \mathrm{Cl}_{2}: \mathrm{MeOH}=90: 10\right.$ to $\left.50: 50\right)$ yielded compound $7 \mathrm{~b}(6.0 \mathrm{mg}, 54 \mu \mathrm{mol}, 77 \%)$ as a white foam. The analytical data matched those reported previously. ${ }^{(5)}$

\section{Cytosine (7b) and 4-thiouracil (7c)}

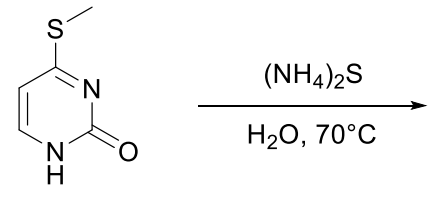

6

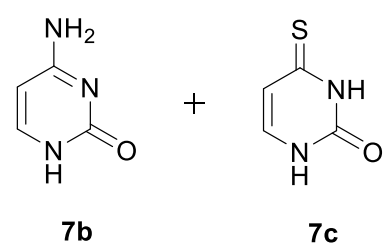

$7 c$

A solution of the compound $6(0.8 \mu \mathrm{mol})$ in $\left(\mathrm{NH}_{4}\right)_{2} \mathrm{~S}(1 \mathrm{ml}, 1,5$ or $10 \%)$ was stirred at $70^{\circ} \mathrm{C}$ for $16 \mathrm{~h}$. The reaction was monitored by HPLC (Fig. S4a-c). The product peaks (compound 7b; Retention time: $7.0 \mathrm{~min}$, compound 7c; Retention time: $10.7 \mathrm{~min}$ ) were isolated and analyzed by NMR measurement by which their structural integrity was confirmed. The analytical data matched those reported previously. ${ }^{(5),(6)}$ The yields of the compound $\mathbf{7 b}$ and $7 \mathrm{c}$ from each reaction were determined according to the calibration curves (Fig. S5c, d). 


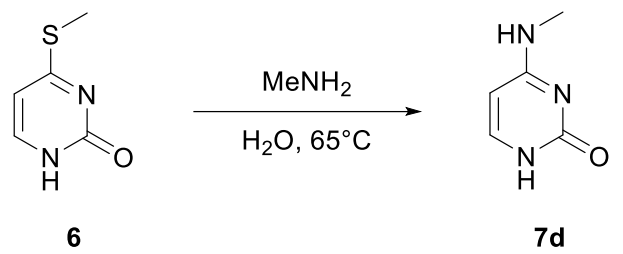

A solution of compound $6(2 \mathrm{mg}, 14.1 \mathrm{\mu mol})$ and methylamine $\left(40 \%\right.$ in $\mathrm{H}_{2} \mathrm{O}, 20$ eq. $)$ in $\mathrm{H}_{2} \mathrm{O}(1 \mathrm{ml})$ was stirred at $70^{\circ} \mathrm{C}$ for $36 \mathrm{~h}$. The reaction was monitored by HPLC (Fig. S4d). The product peak (compound 7d; Retention time: $9.6 \mathrm{~min}$ ) was isolated and analyzed by NMR measurement by which the structural integrity was confirmed. The yield of the compound $\mathbf{7 d}$ was determined according to the calibration curves (Fig. S5e).

IR (neat, cm-1) $2815(\mathrm{w}), 1620(\mathrm{~s}), 1536(\mathrm{~m}), 1516(\mathrm{~m}), 1416(\mathrm{~m}), 1396(\mathrm{~m}), 1380(\mathrm{~m}), 1312(\mathrm{~m}), 1237$ (w), 1175 (w), 1175 (w), 1125 (w), 1064 (w), 1016 (w), 970 (w), $924(\mathrm{~m}), 788(\mathrm{~m}), 775(\mathrm{~m}), 729(\mathrm{~m}),{ }^{1} \mathrm{H}$ NMR (400 MHz, DMSO-d $)^{2} \delta 10.21(\mathrm{~s}, 1 \mathrm{H}), 7.55-7.49(\mathrm{~m}, 1 \mathrm{H}), 7.24(\mathrm{~d}, J=7.0 \mathrm{~Hz}, 1 \mathrm{H}), 5.56(\mathrm{~d}, J=$ $7.1 \mathrm{~Hz}, 1 \mathrm{H}), 2.73$ (d, $J=4.7 \mathrm{~Hz}, 3 \mathrm{H}),{ }^{13} \mathrm{C} \mathrm{NMR}(100 \mathrm{MHz}, \mathrm{DMSO}-d 6) \delta$ 165.4, 157.2, 141.6, 93.7, 27.2, HRMS (ESI) calcd. for $\mathrm{C}_{5} \mathrm{H}_{8} \mathrm{~N}_{3} \mathrm{O}^{+}[\mathrm{M}+\mathrm{H}]+:$ 126.0662, found: 126.0662 .

\section{4,4-Dimethylcytosine (7e)}

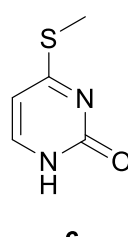

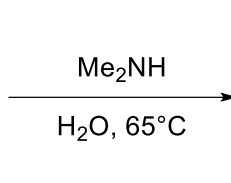

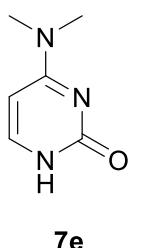

$7 e$

A solution of compound 6 ( $2 \mathrm{mg}, 14.1 \mathrm{\mu mol})$ and dimethylamine (40\% in $\mathrm{H}_{2} \mathrm{O}, 20$ eq.) in $\mathrm{H}_{2} \mathrm{O}(1$ $\mathrm{ml}$ ) was stirred at $70^{\circ} \mathrm{C}$ for $36 \mathrm{~h}$. The reaction was monitored by HPLC (Fig. S4e). The product peak (compound 7e; Retention time: $11.6 \mathrm{~min}$ ) was isolated and analyzed by NMR measurement by which the structural integrity was confirmed. The yield of the compound $7 \mathrm{e}$ was determined according to the calibration curves (Fig. S5f).

IR (neat, cm-1) $3269(\mathrm{w}), 3126(\mathrm{w}), 3046(\mathrm{~m}), 1656(\mathrm{~s}), 1629(\mathrm{~s}), 1604(\mathrm{~s}), 1569(\mathrm{~s}), 1536(\mathrm{~m}), 1471(\mathrm{~m})$, $1426(\mathrm{~s}), 1397(\mathrm{~s}), 1340(\mathrm{~s}), 1293(\mathrm{~m}), 1226(\mathrm{~s}), 1153(\mathrm{~m}), 1083(\mathrm{~m}), 1003(\mathrm{w}), 956(\mathrm{w}), 878(\mathrm{~m}), 816(\mathrm{~s})$, 786 (s), $772(\mathrm{~m}), 750(\mathrm{~m}), 712(\mathrm{~m}),{ }^{1} \mathrm{H}$ NMR (400 MHz, DMSO- $\left.d_{6}\right) \delta 10.43(\mathrm{br}, 1 \mathrm{H}), 7.40$ (d, $J=7.4 \mathrm{~Hz}$, $1 \mathrm{H}), 5.87(\mathrm{~d}, J=7.3 \mathrm{~Hz}, 1 \mathrm{H}), 3.01(\mathrm{br}, 6 \mathrm{H}),{ }^{13} \mathrm{C}$ NMR (100 MHz, DMSO- $d 6$ ) $\delta$ 164.8, 156.4, 143.2, 90.3, HRMS (ESI) calcd. for $\mathrm{C}_{6} \mathrm{H}_{10} \mathrm{~N}_{3} \mathrm{O}^{+}[\mathrm{M}+\mathrm{H}]+:$ 140.0818, found: 140.0818 . 
(a) $1 \%\left(\mathrm{NH}_{4}\right)_{2} \mathrm{~S}$

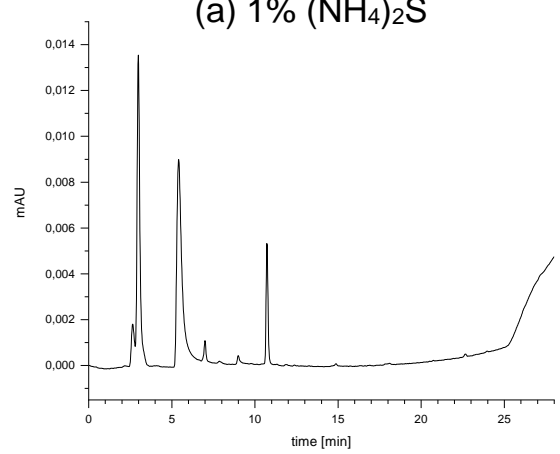

(b) $5 \%\left(\mathrm{NH}_{4}\right)_{2} \mathrm{~S}$

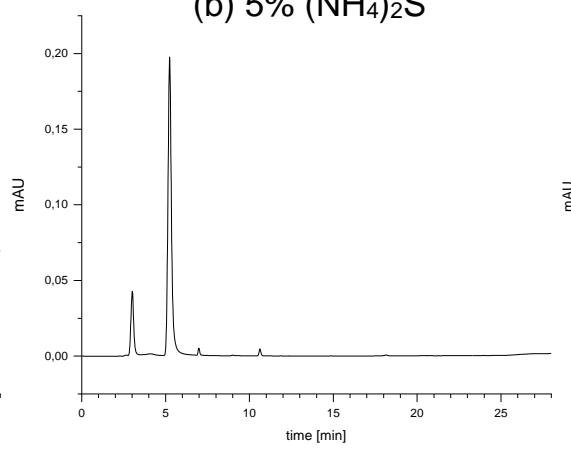

(c) $10 \%\left(\mathrm{NH}_{4}\right)_{2} \mathrm{~S}$

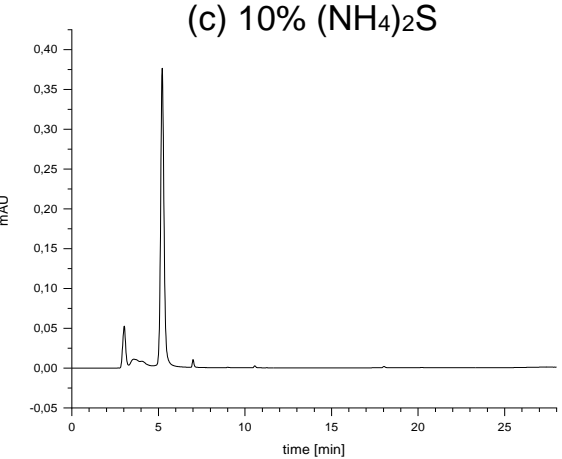

(d) 20 eq. $\mathrm{H}_{2} \mathrm{NMe}$

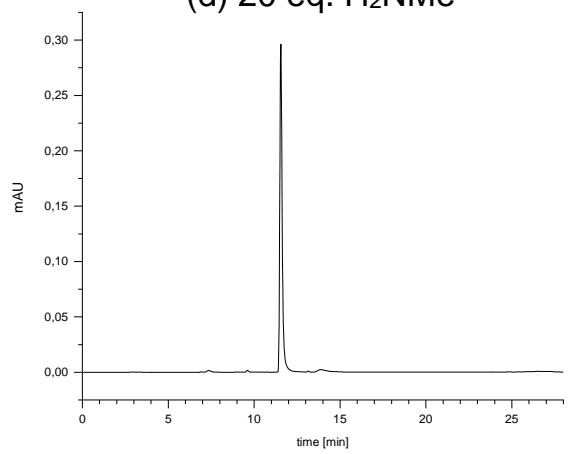

(e) 20 eq. $\mathrm{HNMe}_{2}$

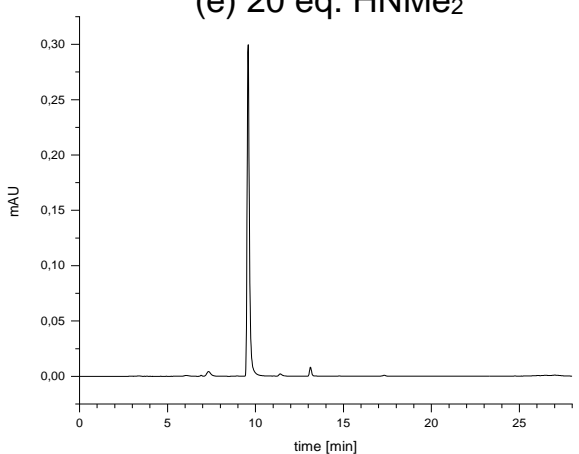

Figure S4. HPLC analysis of 4-substituted pyrimidine syntheses. 
7. Calibration curves of the compounds synthesized in this study

To determine the concentration of a compound by HPLC a solution of the respective compound with a known concentration was made three times. The integrals and the arithmetic middle were calculated, and the average area under the curve from three independent experiment was plotted against the concentration. A regression line was generated and its equation was extracted.

(a) Thioamide 3

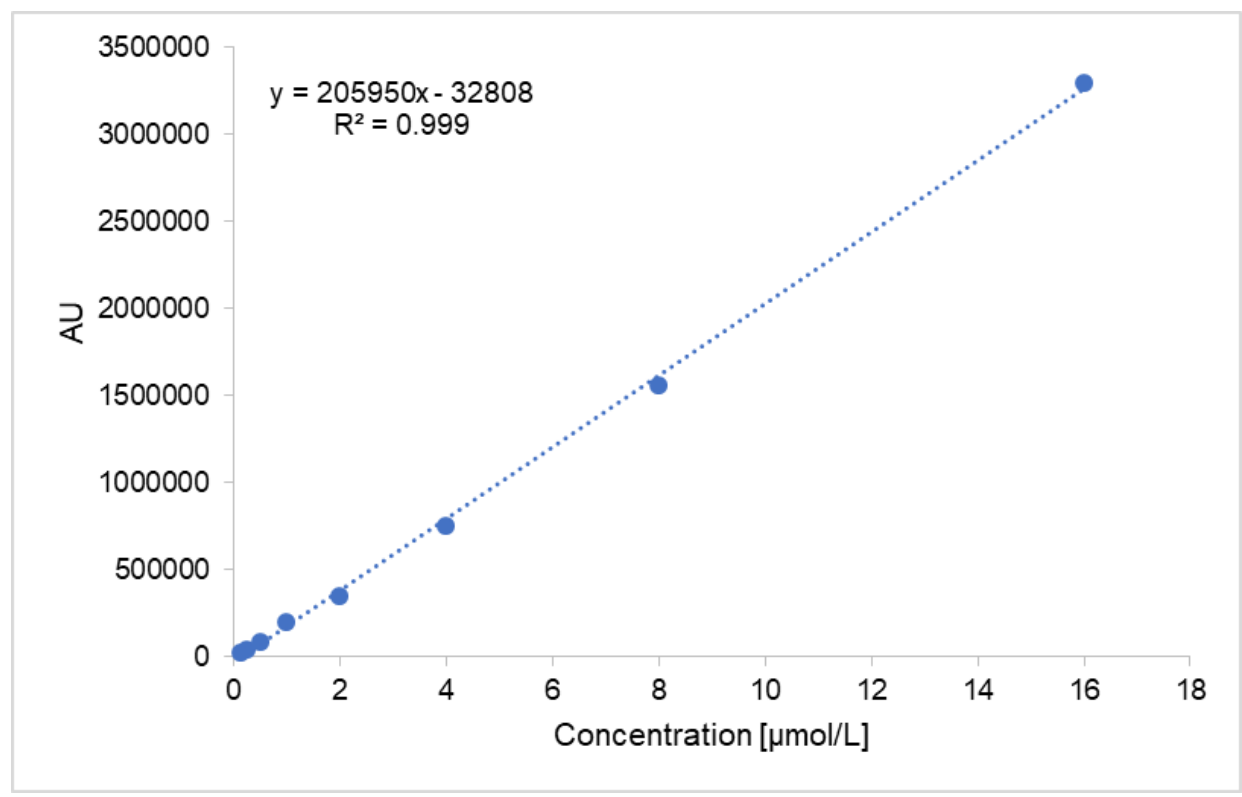

(b) SMePy 6

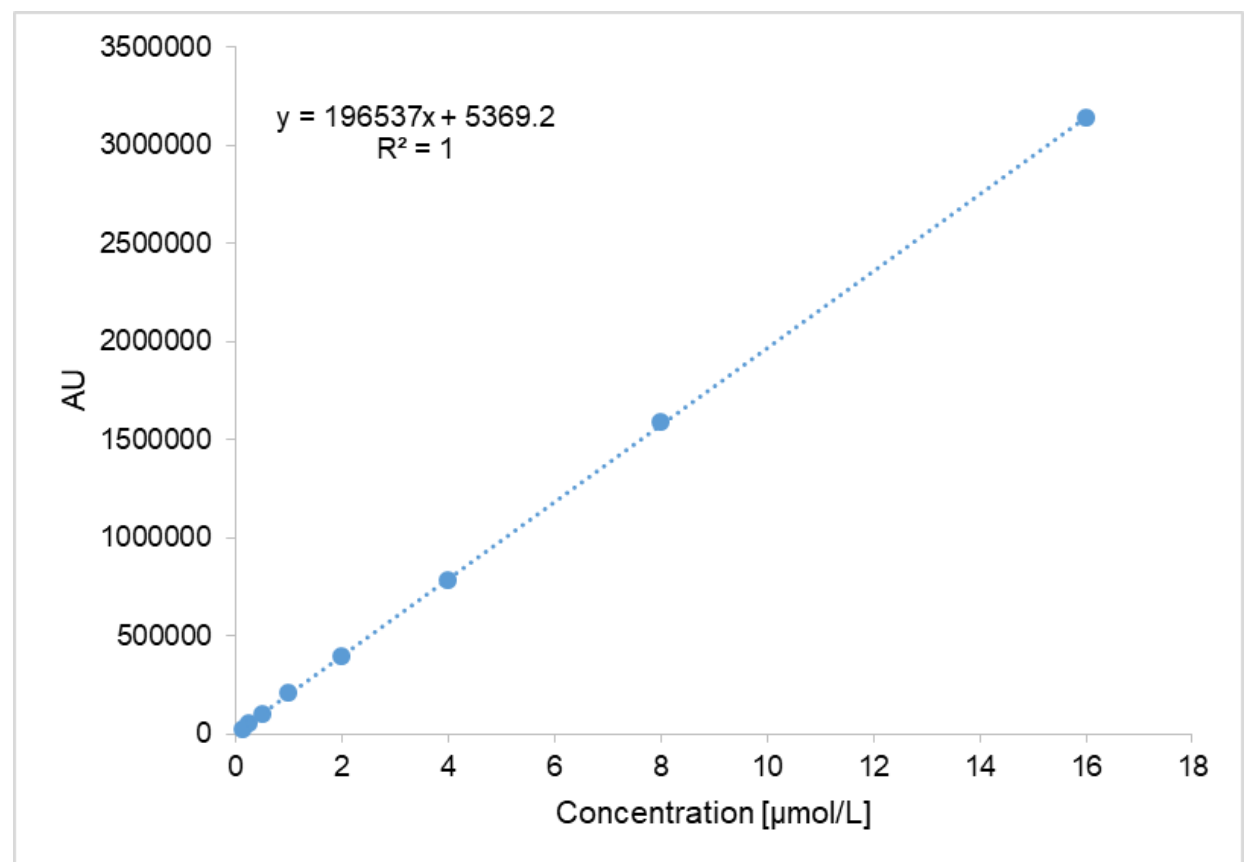

Figure S5. Calibration curves of the compounds synthesized in this study. 
(c) Cytosine 7b

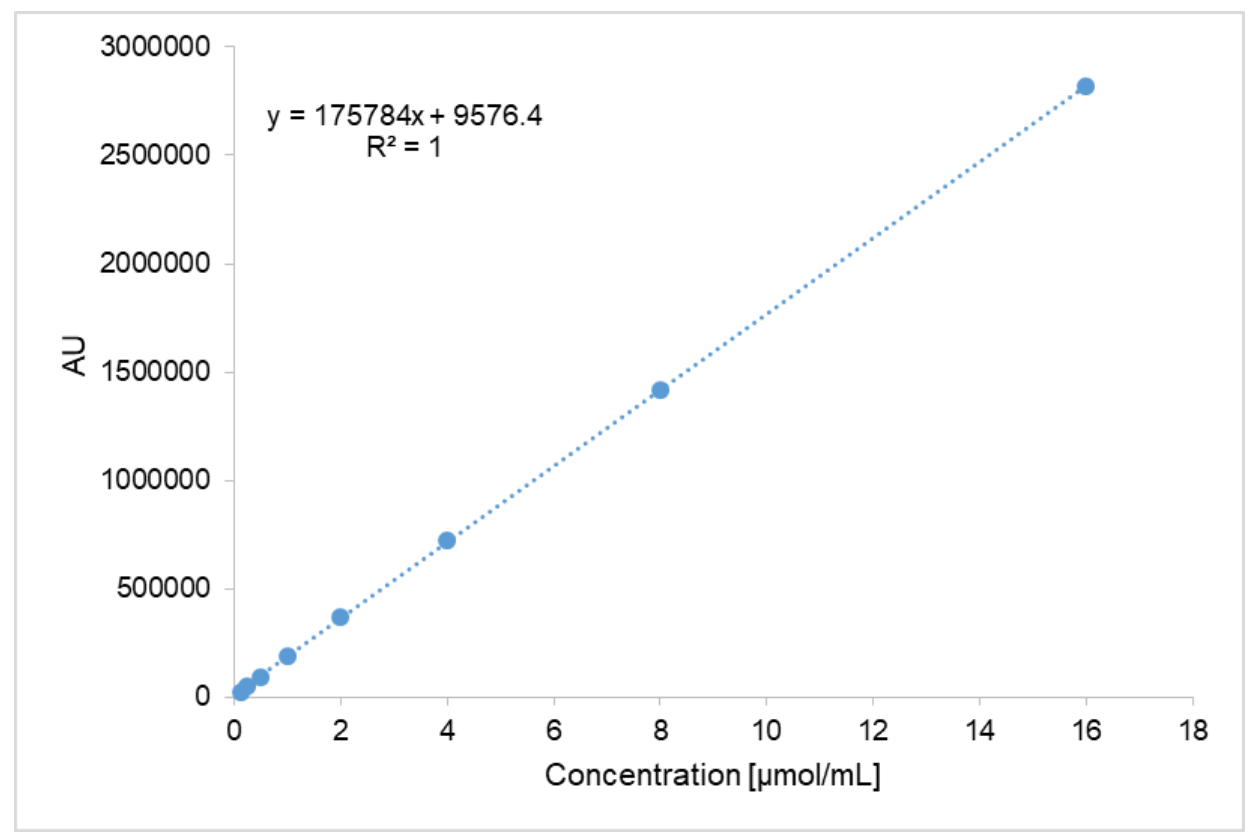

(d) 4-Thiouracil 7c

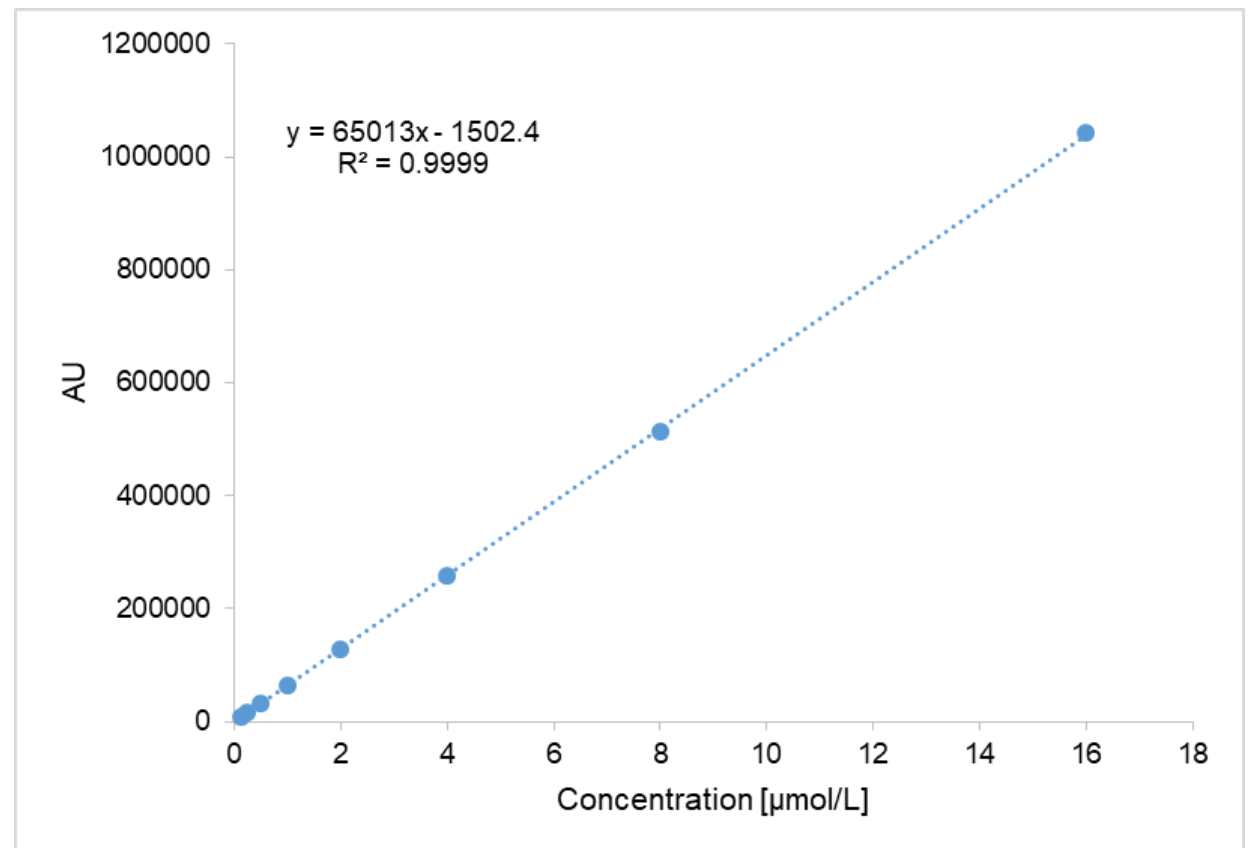

Figure S5 (continued). Calibration curves of the compounds synthesized in this study. 
(e) 4-Methylcytosine

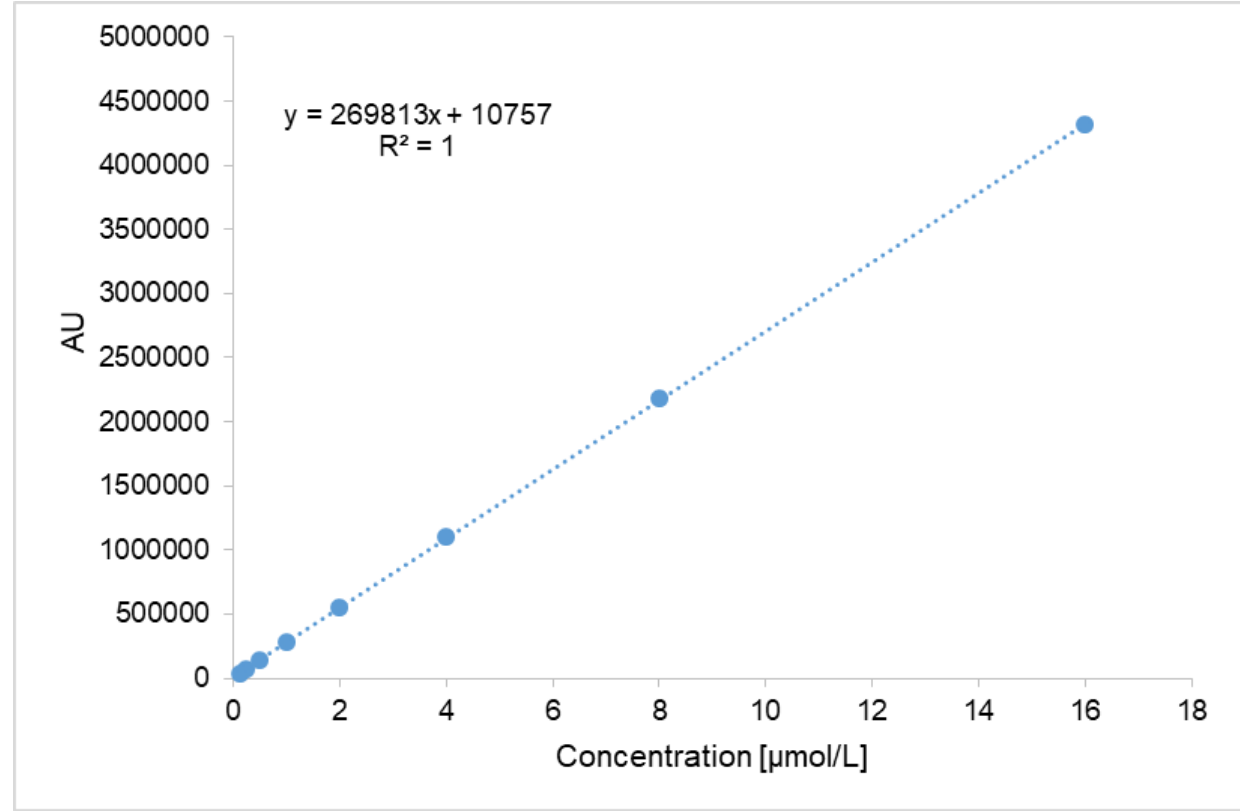

(f) 4,4-Dimethylcytosine

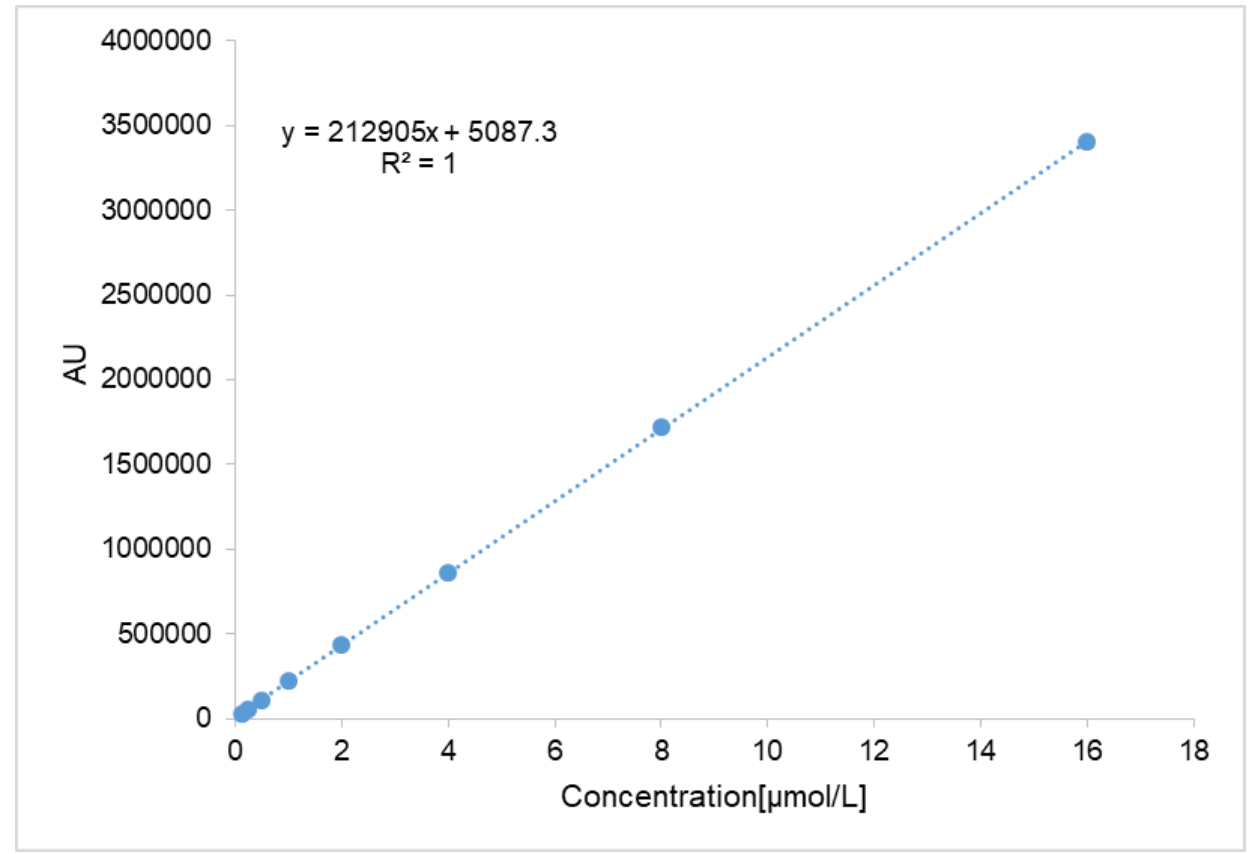

Figure S5 (continued). Calibration curves of the compounds synthesized in this study. 
8. ${ }^{1} \mathrm{H}$ and ${ }^{13} \mathrm{C}$ NMR spectra of the compounds ${ }^{1} \mathrm{H}$ NMR and ${ }^{13} \mathrm{C}$ NMR of the compound 2
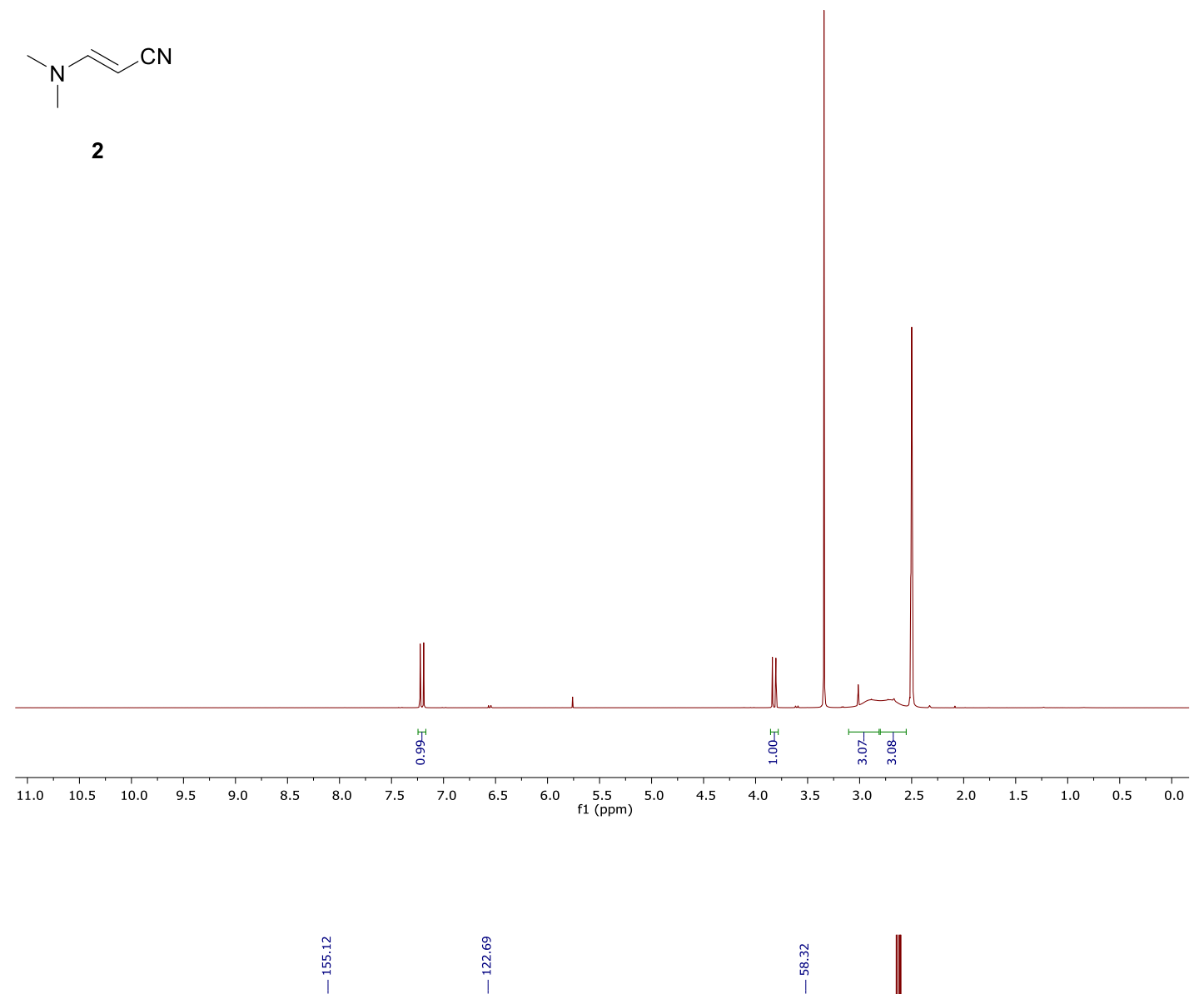
${ }^{1} \mathrm{H}$ NMR and ${ }^{13} \mathrm{C}$ NMR of the compound 3
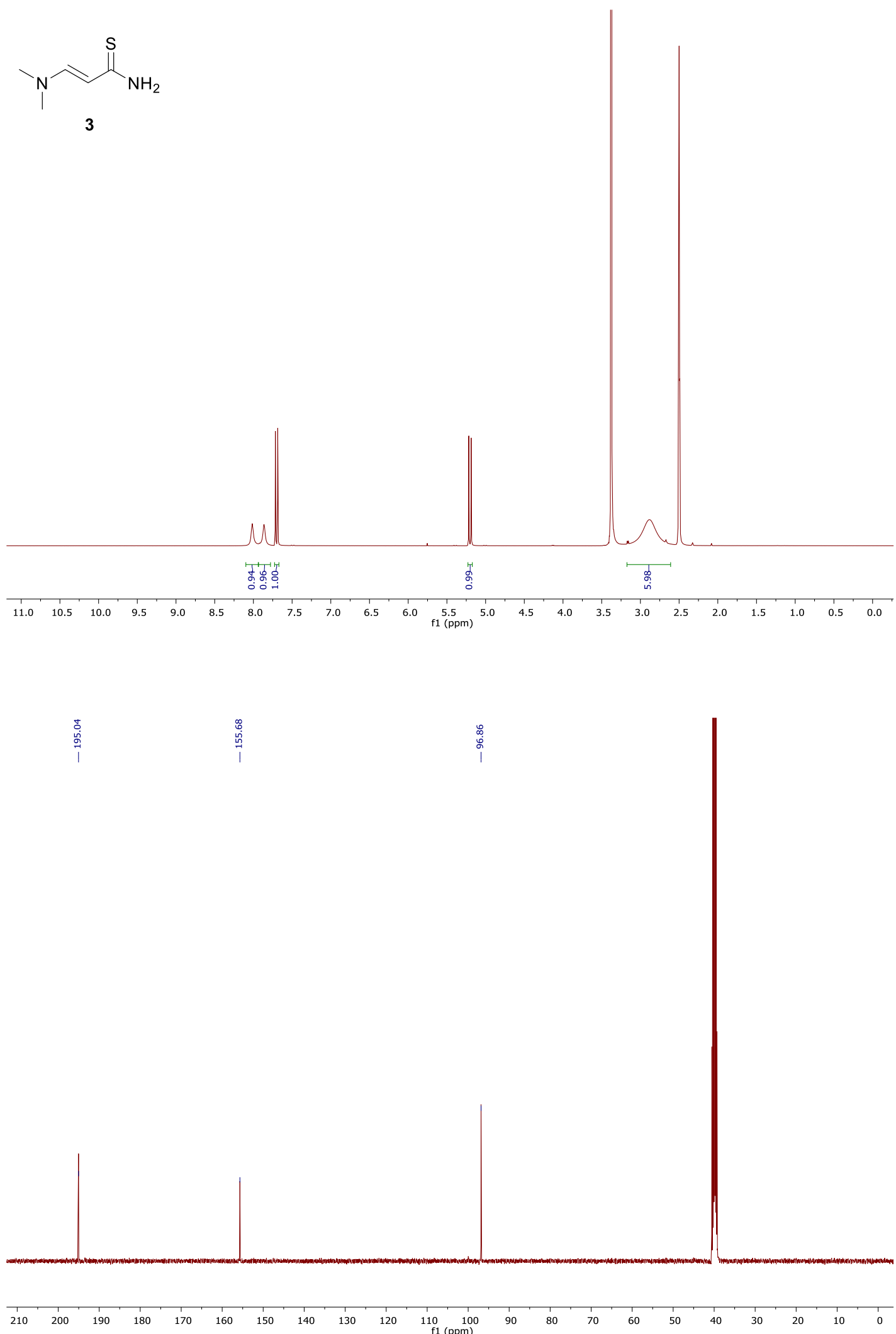
${ }^{1} \mathrm{H}$ NMR and ${ }^{13} \mathrm{C}$ NMR of the compound 6
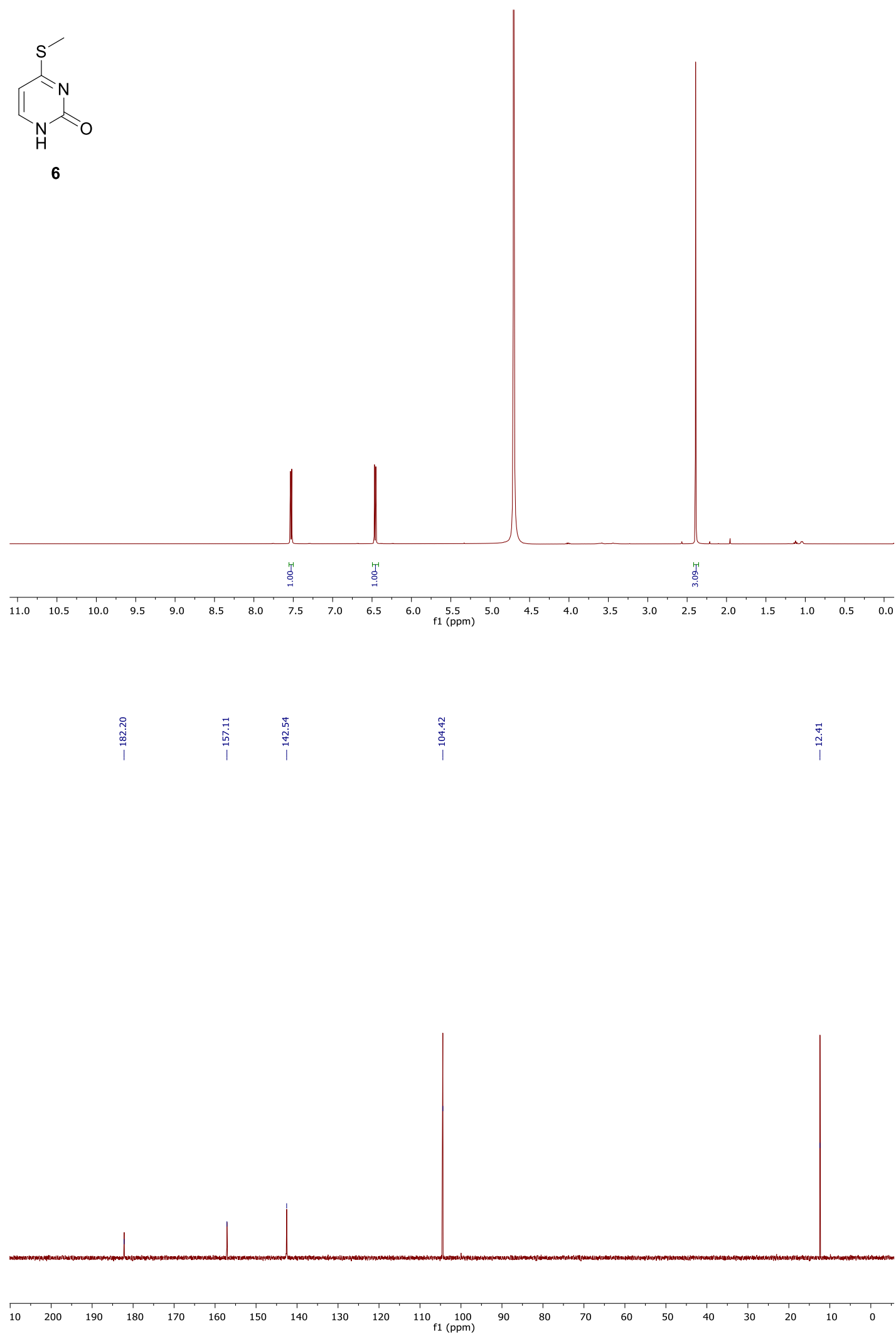
${ }^{1} \mathrm{H}$ NMR and ${ }^{13} \mathrm{C}$ NMR of the compound $7 \mathrm{~d}$

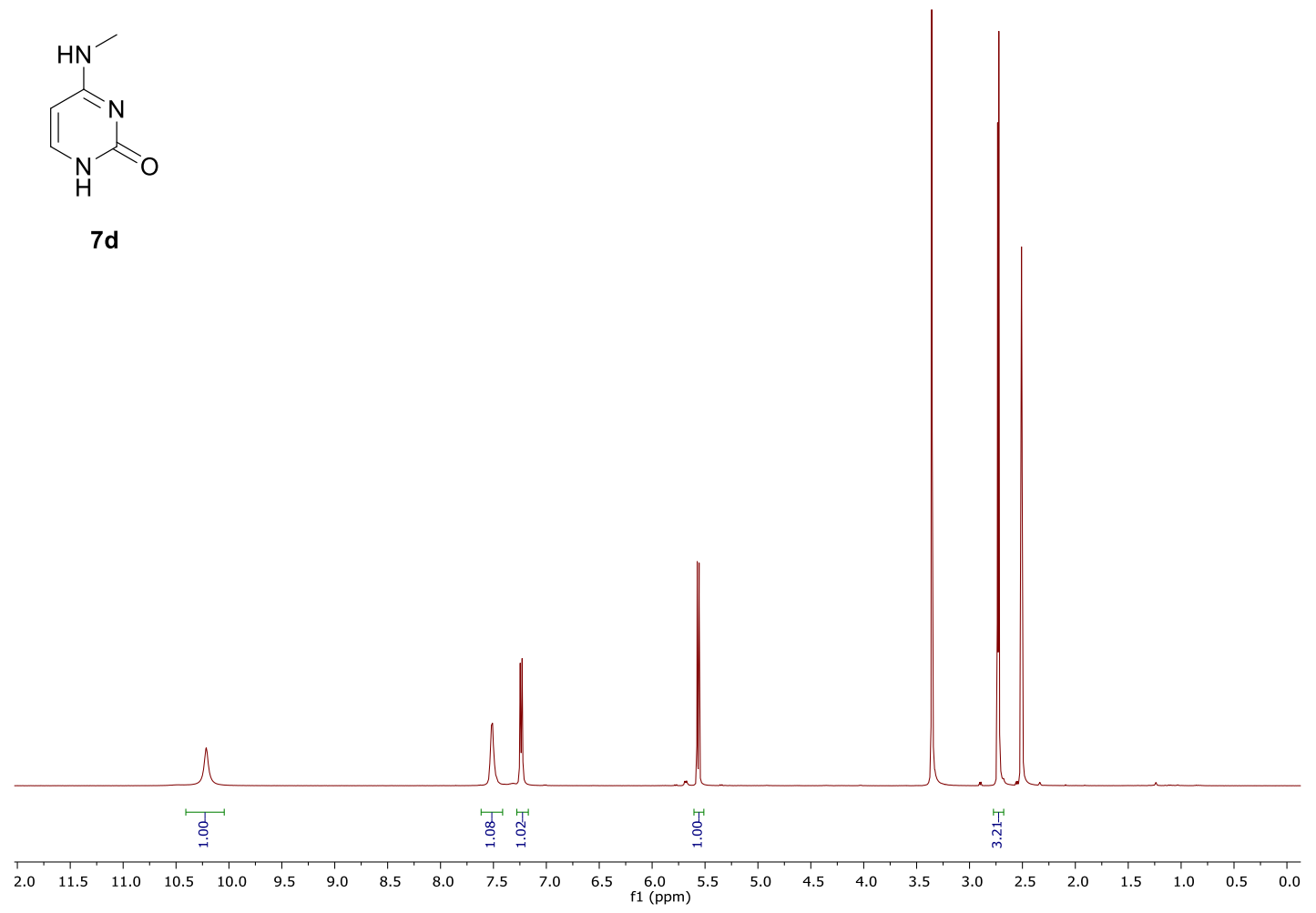

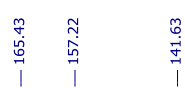
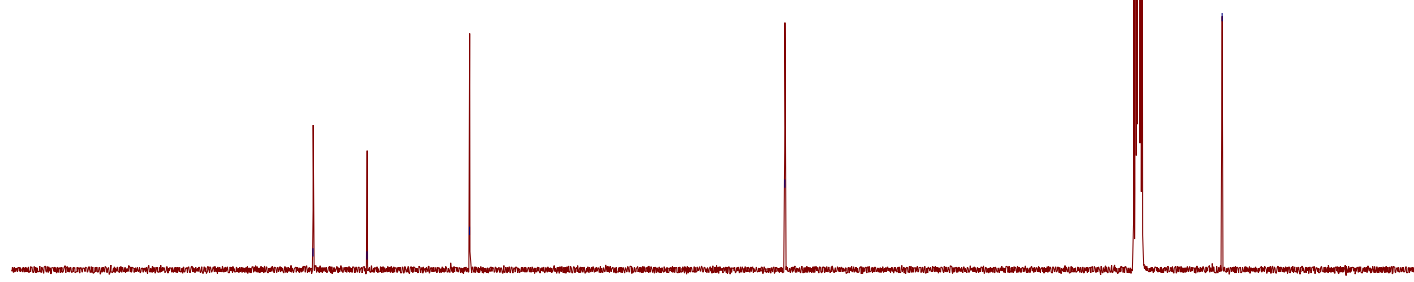

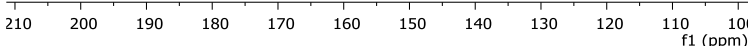


${ }^{1} \mathrm{H}$ NMR and ${ }^{13} \mathrm{C}$ NMR of the compound $7 \mathrm{e}$
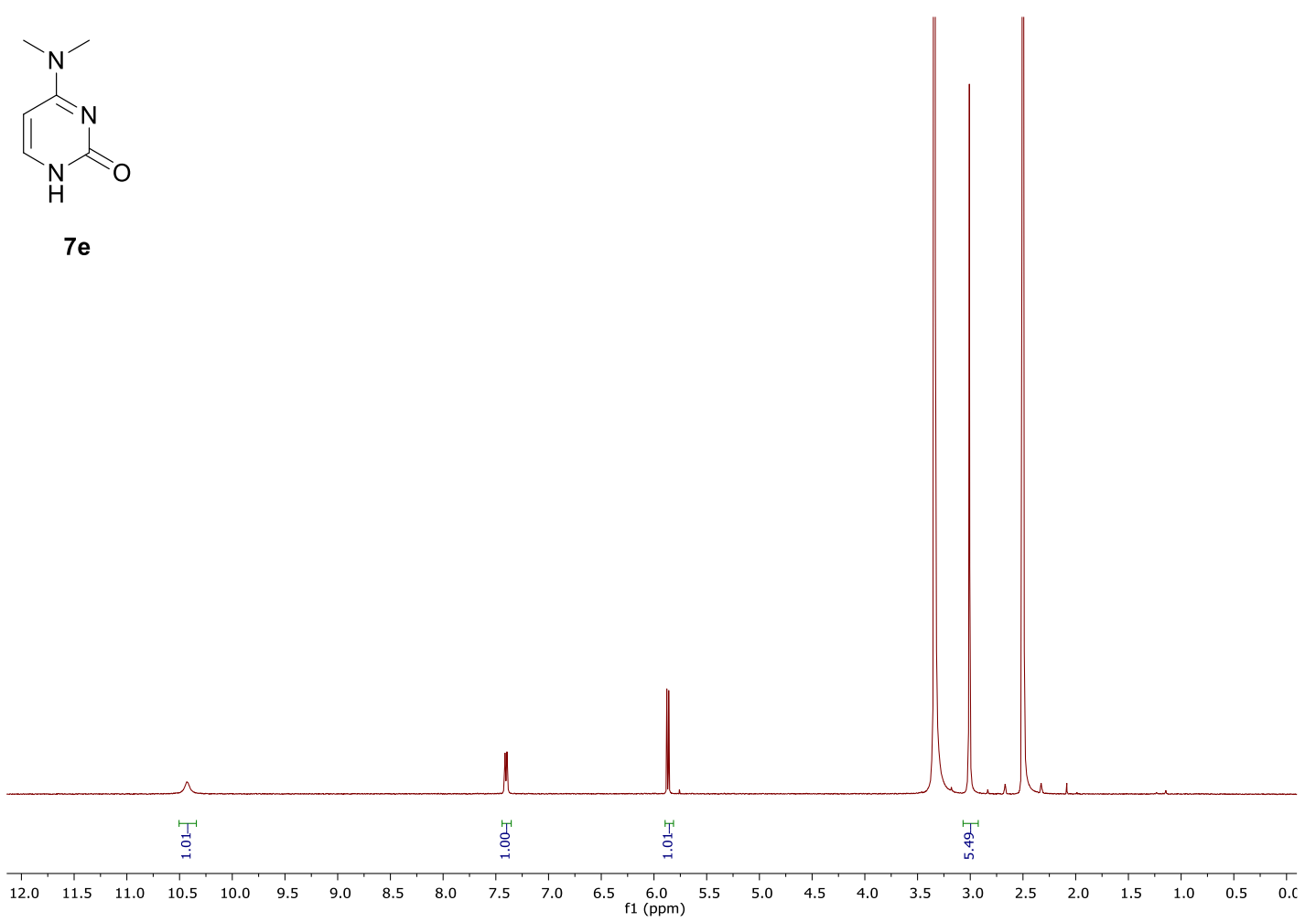

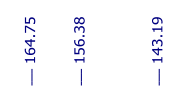

m̊̀

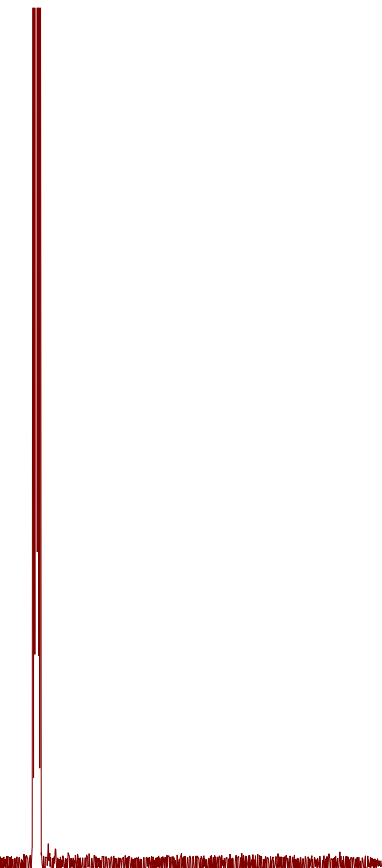

$\begin{array}{llllllllllll}210 & 200 & 190 & 180 & 170 & 160 & 150 & 140 & 130 & 120 & 110 & 100 \\ \mathrm{f} 1(\mathrm{ppm})\end{array}$ 
9. HRMS spectra of compound 2 and 3

HRMS (EI+) spectrum of compound 2

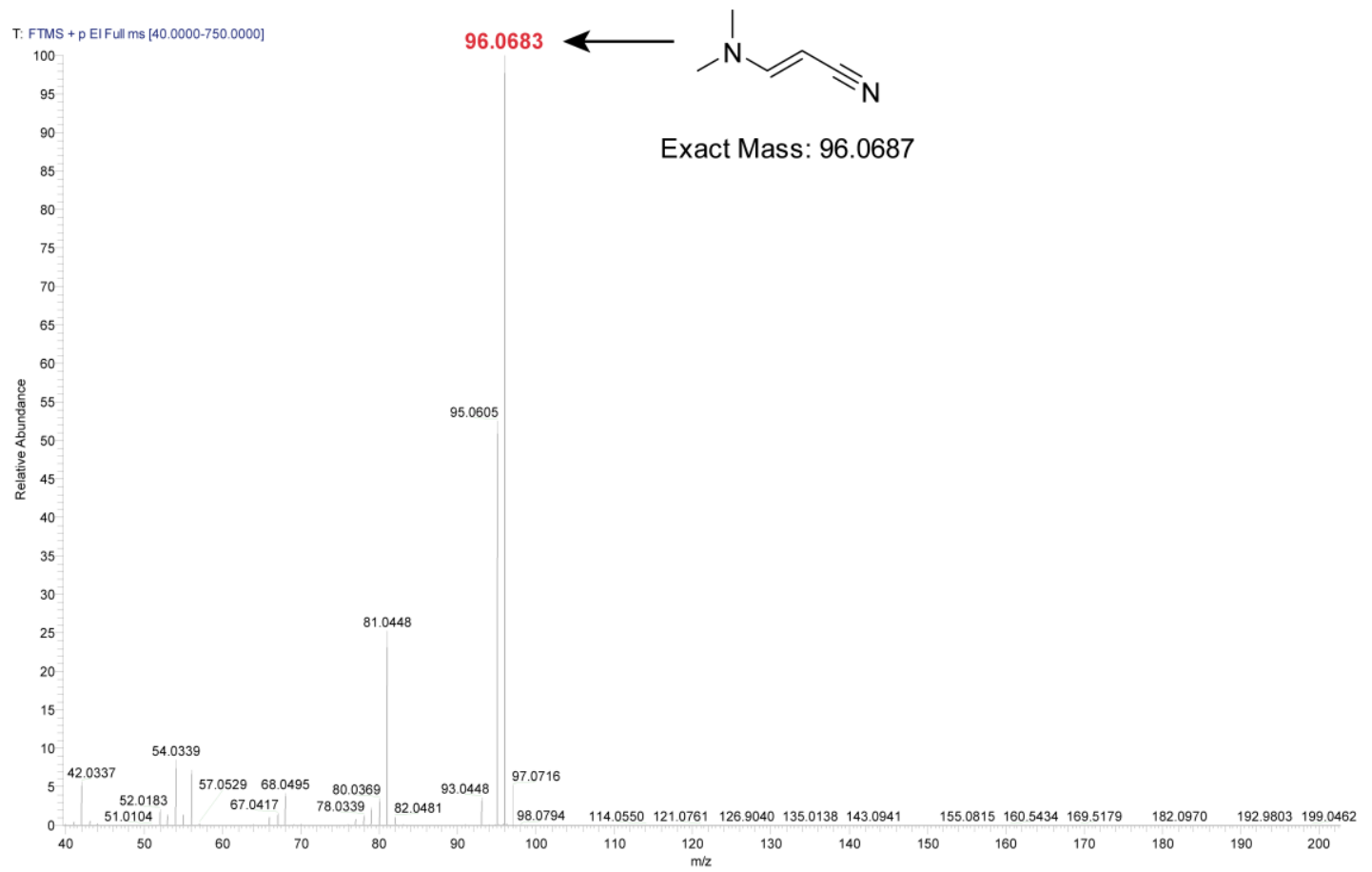

HRMS (EI+) spectrum of compound 3

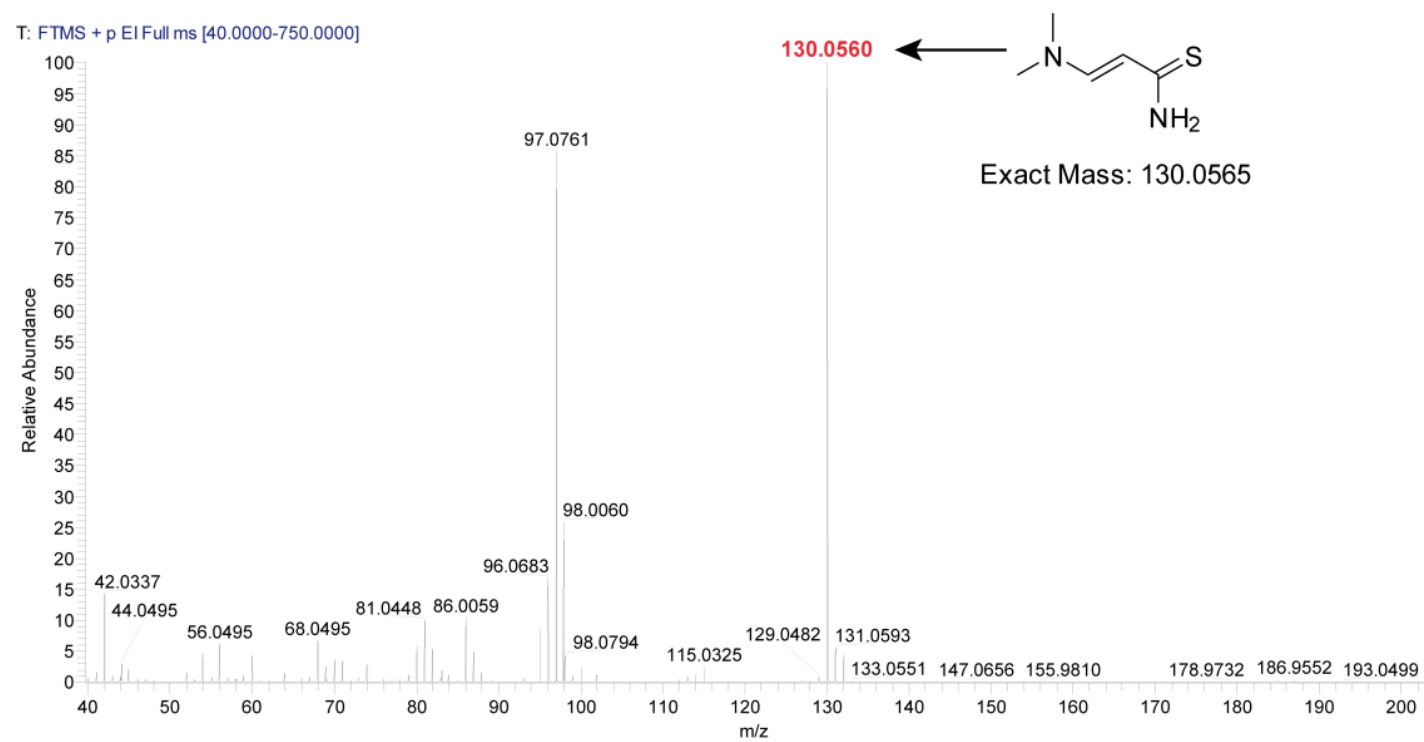


10. References

(1) M. S. M. Pearson, A. Robin, N. Bourgougnon, J. C. Meslin, D. Deniaud, J. Org. Chem., 2003, $68,8583-8587$.

(2) B. T. Golding, C. Bleasdale, J. McGinnis, S. Müller, H. T. Rees, N. H. Rees, P. B. Farmer, W. P. Watson, Tetrahedron, 1997, 53, 4063-4082.

(3) T. J. Delia, M. J. Olsen, G. B. Brown, J. Org. Chem., 1965, 30, 2766-2768.

(4) N. P. Dolman, H. M. Troop, J. C. A. More, A. Alt, J. L. Knauss, R. Nistico, S. Jack, R. M. Morley, Z. A. Bortolotto, P. J. Roberts, D. Bleakman, G. L. Collingridge, D. E. Jane, J. Med. Chem., 2005, 48, 7867-7881.

(5) A. Shaw, M. D. Shetlar, J. Am. Chem. Soc., 1990, 112, 7736-7742.

(6) M. Masaki, K. Kazusaki, K. Shigeo, S. Katsuyoshi, M. Hiroshige, Bull. Chem. Soc. Jpn., 1989, 62, 2939-2941. 